\title{
Legal Mobilization in Schools: The Paradox of Rights and Race Among Youth
}

\author{
Calvin Morrill \\ Lauren B. Edelman
}

Karolyn Tyson
Richard Arum

\begin{abstract}
In this article, we analyze ethnoracial patterns in youth perceptions and responses to rights violations and advance a new model of legal mobilization that includes formal, quasi-, and extralegal action. Slightly more than half of the $\mathbf{5 , 4 6 1}$ students in our sample reported past rights violations involving discrimination, harassment, freedom of expression/assembly, and due process violations in disciplinary procedures. Students, regardless of race, are more likely to take extralegal than formal legal actions in response to perceived rights violations. Self-identified African American and Latino/a students are significantly more likely than white and Asian American students to perceive rights violations and are more likely to claim they would take formal legal action in response to hypothetical rights violations. However, when they perceive rights violations, African American and Asian American students are no more likely than whites to take formal legal action and Latino/a students are less likely than whites to take formal legal action. We draw on in-depth
\end{abstract}

Authorship of this article is fully collaborative. First and foremost, our thanks go to the students, teachers, administrators, and other persons who participated in this study and facilitated access to schools. Audiences at the following venues provided useful comments on earlier drafts of this article: Conference on Empirical Legal Studies, University of Southern California Law School; Hastings School of Law, San Francisco; American Sociological Association annual meetings, San Francisco; Berkeley Empirical Legal Studies Conference, School of Law, University of California, Berkeley; School of Education and Department of Sociology, Stanford University; Center for the Study of Law and Society, University of California, Berkeley; Law \& Society Association annual meetings, Montreal; and the Conference on the Paradoxes of Race, Law, and Inequality in the United States, University of California, Irvine. The National Science Foundation, Spencer Foundation, Ewing Marion Kauffman Foundation, and other private foundations provided financial support for this research. We thank all the members of the School Rights Project team, especially Melissa Velez and Doreet Preiss, for their research assistance on the quantitative analyses; and Catherine Bell, Joseph Christoff, Jessica Hardy, Yuki Kato, Gerald Lackey, Leah Reich, Eva Ruiz, and Meagan Theil, for their qualitative fieldwork and analyses. For their comments, we thank Catherine Albiston, Kitty Calavita, Prudence Carter, Elisabeth Clemens, Malcolm Feeley, Stephen Galoub, Laura Gómez, Tristin Green, Antoinette Hetzler, Eric Ishiwata, Valerie Jenness, Robert Kagan, Gwendolyn Leachman, Ian Haney López, Robert MacCoun, Anna-Maria Marshall, Justin McCrary, Michael Musheno, Laura Beth Nielsen, Robert Nelson, Walter Powell, James Rule, Katheryn Russell-Brown, Marc Schneiberg, W. Richard Scott, Richard Shavelson, Susan Silbey, Sarah Song, Stephen Sugarman, Geoff Ward, and, from the Law E Society Review, editor Carroll Seron and three reviewers. Finally, we thank the American Bar Foundation for providing the School Rights Project team with meeting space in October 2007. Please address all correspondence to Calvin Morrill, Center for the Study of Law and Society, School of Law, University of California, Berkeley, 2240 Piedmont Ave., Berkeley, CA 94720; e-mail: cmorrill@ law.berkeley.edu.

Law $\mathcal{E}^{\circ}$ Society Review, Volume 44, Number 3/4 (2010)

(C) 2010 Law and Society Association. All rights reserved. 
interviews with youth and adults- which we interlace with our quantitative findings - to explore the interpretive dynamics underlying these survey findings, and we offer several theoretical and methodological implications of our work.

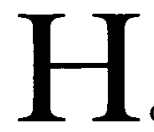

ow do rights matter in schools? One answer to this question suggests that Americans increasingly look to the "realization" of legal rights to solve racial and ethnic segregation, inequality, and injustice in educational contexts (Arum 2003). A deep commitment to this approach underlies the 1964 Civil Rights Act, Brown v. Board of Education (1954), and other landmark Supreme Court decisions, such as Tinker v. Des Moines Independent School District in 1969 and Goss v. Lopez in 1975, which expanded students' rights with respect to freedom of expression and the right of due process for disciplinary actions in public schools, respectively.

A very different picture of legal rights in contemporary American society emerges from studies of legal mobilization outside educational contexts. Multiple generations of researchers have demonstrated that American adults rarely turn to lawyers or the courts when they define experiences as rights violations, instead taking a range of actions apart from law or absorbing perceived wrongs without overt response (Baumgartner 1988; Black 1983; Bumiller 1987, 1988; Cooney 1998; Engel \& Munger 2003; Ewick \& Silbey 1998; Felstiner et al. 1980-81; Friedman 1985; Fuller et al. 2000; Galanter 1983; Miller \& Sarat 1980-81; Scheingold 1974). This paradox - between legal rights as a sought-after guarantee of social justice and legal rights as a little-used means of redress in the face of social injustice-is especially apparent for socially disadvantaged racial and ethnic groups. Such groups have collectively invested the most in attaining legal rights, especially civil rights, as a means of redressing social injustice in American society, but they are also relatively unlikely, especially at the individual level, to invoke legal rights when faced with perceived rights violations (Black 1976; Bumiller 1987, 1988; Curran 1977; Engel \& Munger 2003; Mayhew \& Reiss 1969; Miller \& Sarat 1980-81).

Much of the law applied to U.S. students over the past half century has been intended to benefit nonwhite youth, but to date there has not been empirical research on the mobilization of rights among youth. In this article, we explore the paradox of rights and race in high schools by examining whether and how students who self-identify as white and nonwhite mobilize their rights in response to both hypothetical scenarios and self-reports of actual rights violations involving discrimination, harassment, freedom of 
speech, and disciplinary procedures. ${ }^{1}$ By examining both what individuals claim they would do and what they report they actually did in response to rights violations, we examine the relationship between hypothetical and actual rights mobilization, two aspects of the law-in-action that are rarely investigated in the same study. These aspects of mobilization, we believe, are crucial for understanding the paradox of rights and race in schools and other contexts. We base our analyses on surveys of 5,461 students in California, New York, and North Carolina, and in-depth interviews with students and school personnel that make up part of our broader School Rights Project (SRP) - a multimethod study of law and everyday life in American high schools.

We conceptualize responses to rights violations as a multidimensional process involving a variety of actions that may or may not include law in any direct way. How youth interpret and respond to situations as rights violations is integrally bound up in the ongoing interactional dynamics through which they define who they are and where they belong in the social fabric-their selfidentities (Engel \& Munger 2003; Oberweis \& Musheno 1999). During adolescence, self-identity becomes especially salient for youth and a key lens for interpreting their own and others' actions (Erikson 1968).

Of particular importance for the normative domains we examine are self-identities related to the social categories of "youth" and race and ethnicity. ${ }^{2}$ Adolescence is a time when youth develop an acute sense of how formal rules and procedures, especially in schools, influence their lives (Fagan \& Tyler 2005). To the degree that youth identify as members of socially disadvantaged ethnoracial categories, they can become attuned to everyday ethnoracial injustice, including disparate treatment of white and nonwhite youth in security and disciplinary procedures by school authorities (Kupchik 2009; Welch \& Payne 2010). Youth also can become aware of societal "myths" about the efficacy of law and rights for achieving ethnoracial justice (Scheingold 1974). Youth identity is thus intimately linked with the sociocultural processes of forming and acting on "commonsense understanding[s] about how law

' For ease of exposition, we use "actual" or "past" rights violations to refer to youths' self-reported, subjective perceptions of rights violations.

2 For present purposes, we define race as "groups that distinguish themselves on the basis of ancestry and/or [skin] color" (J. Lee \& Bean 2004:223; see also Obasogie 2006). We recognize that for many groups the terms race and ethnic identity are blurred. As J. Lee and Bean (2004:223) observe, "Some new Latino immigrants, for example, view themselves and are viewed by others as white, some as mestizo, and a few as African American." Thus, we use the term ethnoracial to reflect this blurring (T. Lee 2009) and recognize the challenges in conceptually and empirically characterizing race and ethnicity as socio-historical, legal constructions (Gómez 2004; Zatz \& Rodriguez 2006). 
works"-legal consciousness (Nielsen 2004:7; see also Engel \& Munger 2003; Ewick \& Silbey 1998; Merry 1990).

In the next section we develop our notion of legal mobilization as a multidimensional process and then, in a following section, suggest a number of hypotheses about the relationships between youth, ethnoracial self-identity, and perceptions of and responses to rights violations. We then describe our survey and qualitative methods. Our findings interlace quantitative patterns from our survey results with representative excerpts from in-depth interviews with youth and adults. We conclude by suggesting some theoretical implications of our work for the interplay of youth legal mobilization, self-identity, and racial and ethnic inequality in schools.

\section{Conceptualizing Legal Mobilization}

Legal mobilization refers to the social processes through which individuals define problems as potential rights violations and decide to take action within and/or outside the legal system to seek redress for those violations (Albiston 2005; Black 1973; Bumiller 1987, 1988; Felstiner et al. 1980-81; Hirsh \& Kornrich 2008; Hoffman 2005; Kessler et al. 1999; Marshall 2005; Michelson 2007; Miller \& Sarat 1980-81; Nielsen \& Nelson 2005; Nielsen 2004; Scheingold 1974). ${ }^{3}$ Our conceptual approach to legal mobilization specifically builds on three well-known literatures within the law and society tradition on the management of conflict. The first of these literatures is the dispute transformation framework, which depicts the natural history of disputing as evolving through a number of stages on the way to an articulated claim for redress against a party or parties identified as at fault (Felstiner et al. 1980-81). In contemporary American society, few disputes are transformed into legal claims, and the aggregate evolution of disputes tends to graphically resemble a pyramid, with a broad base of grievances and rights violations, but strong attrition so that only about 5 percent of all grievances reach the trial stage (Michelson 2007; Miller \& Sarat 1980-81; compare Nader \& Todd 1978).

The other two literatures we draw on investigate actions that operate tangentially or wholly apart from formal law. One of these literatures focuses on disputing in the "shadow" of law (Mnookin \& Kornhauser 1979), involving constellations of law-like procedures, such as organizational grievance procedures, mediation, or arbitration

\footnotetext{
3 This process is somewhat, but not entirely, distinct from the collective mobilization processes that social movement scholars study, which can encourage individual legal mobilization or vice versa (Edelman, McAdam, et al. n.d.; McCann 1994).
} 
(Albiston 2005; Edelman \& Suchman 1999; Edelman, Erlanger, et al. 1993; Felstiner 1974; Heimer 1999). The last literature we draw on explores the range of actions that people take outside the law to pursue rights violations, including coercive and remedial self-help, bilateral negotiation, avoidance, covert actions, and "lumping" (Baumgartner 1988; Black 1983; Ellickson 1991; Emerson 2008; Macaulay 1963; Morrill 1995).

In drawing from these sources, we conceive of legal mobilization as emerging out of a pool of perceived rights violations (which may or may not have a basis in formal law) and comprising multiple modes of action: (1) formal legal action, such as filing a formal lawsuit, filing a formal complaint with a government agency (e.g., the Equal Employment Opportunity Commission), or contacting a lawyer; (2) quasi-legal action, such as using formal complaint procedures provided by the school, district, or equivalent organization (e.g., an archdiocese), or using some sort of internal dispute resolution forum (i.e., mediation, peer counseling, etc.); (3) extralegal action, such as contacting the media, directly confronting a person verbally or physically, seeking support from a counselor or religious professional, avoiding the person, talking with peers or family members, or engaging in prayer; and (4) doing nothing ("lumping it").

In Figure 1, we overlay our conceptual model of legal mobilization on the outline of the classic dispute pyramid (Miller \& Sarat 1980-81). With the exception of doing nothing, these responses are not mutually exclusive as youth (or adults) can pursue several strategies at once. Moreover, they may not unfold in temporally linear ways (e.g., from more formal to less formal or vice versa). Instead, we view these strategies as potentially reinforcing, but also potentially in conflict with each other depending upon their

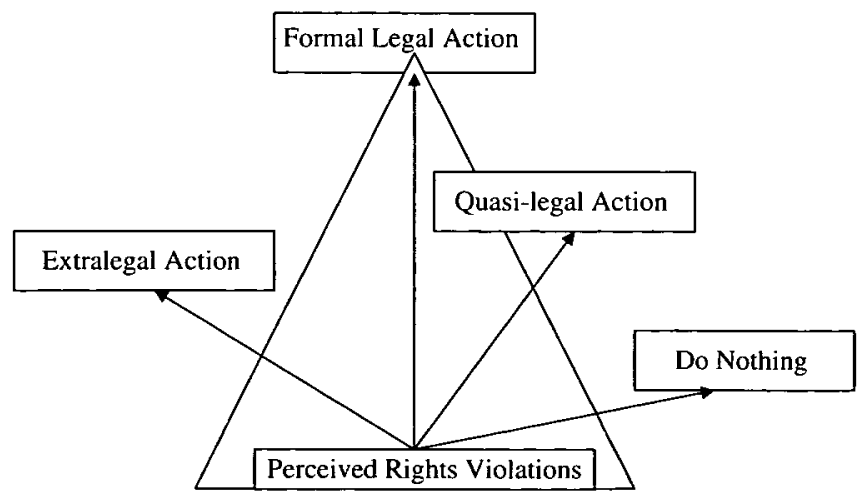

Figure 1. Conceptual Model of Legal Mobilization as Multidimensional. 
salience and meaning in particular sociocultural contexts. By conceiving of mobilization as a multidimensional process, our approach can potentially reveal a broader range of options that youth have for mobilizing their rights apart from law and a framework for examining whether youth combine different options as they mobilize their rights.

\section{A Sociolegal Perspective on Youth, Identity, and Legal Mobilization}

We theoretically ground the definition of and responses to rights violations in the concept of self-identity, which not only refers to the social processes through which people come to recognize themselves and others but also provides a basis for evaluating one's own actions and those of others (Oberweis \& Musheno 1999:899-900). In adolescence, self-identity becomes especially salient as youths increasingly question who they are, what they hope to be, and the ways they plan to conduct their lives (Erikson 1968; White \& Wyn 2008:191-209). Self identity is always contingent and interactional, and contains multiple components that may or may not be consistent with one another.

\section{How Youth Mobilize Rights}

Research on the sociology of adolescence and youth culture generally suggests that youth actively carve out autonomous social worlds apart from the gaze, control, and protection of adults (Coleman 1961; Dornbusch 1989; Skelton \& Valentine 1998; Weis \& Fine 2000; White \& Wyn 2008). Multiple qualitative studies in schools and communities have documented the predominance of extralegal actions that youth take to manage peer conflict and trouble with adults involving actions intended to alter the conditions under which rights violations occur or avoid offending parties (Carter 2005; Emerson 2008; Garot 2007, 2009; Morrill \& Musheno, forthcoming; Morrill, Yalda, et al. 2000). With respect to teachers and other adults (especially in positions of official authority), some actions along these lines can involve various kinds of resistance (McFarland 2001, 2004). Aside from their own agency in handling conflict, youth may also perceive their standing as minors and their relative power as youth vis-à-vis adults as formal barriers to mobilizing law or taking quasi-legal action (Fine et al. 2003). Therefore, we posit that youth are in general more likely to turn to extralegal forms of rights mobilization. 
Hypothesis 1: In response to hypothetical scenarios containing rights violations, youth are more likely to claim that they would take extralegal action than mobilize formal law, take quasi-legal action, or do nothing.

Hypothesis 2: In response to actual rights violations, youth are more likely to report they took extralegal action than mobilized formal law, took quasi-legal action, or did nothing.

\section{How Race Matters in Youth Perceptions of Rights Violations}

As youth who identify as African Americans and/or Latinos/as navigate their high schools, they can become especially aware of their collective, subordinated status in local and national-level ethnoracial hierarchies, particularly when they encounter institutional "messages that education does not pay and that discrimination prevents people of color from ever succeeding" (Portes \& Rumbaut 2001:61; see also Carter 2005; Hallinan 2001; Oakes 1985; Rosigno \& Ainsworth-Darnell 1999; Telles \& Ortiz 2008; Tyson et al. 2005; Walters \& Briggs 1993; Waters \& Eschbach 1995). In this context, youths' self-identities as African Americans and/or Latinos/as can become a key way of organizing their orientations and expectations toward their daily experiences with legal and other agents of institutionalized authority (Flanagan \& Sherrod 1998; Hagan, Hirschfield, et al. 2002:242-3; Hagan, Shedd, et al. 2005:383-5; Helwig 1995). ${ }^{4}$ Students who identify as white also tacitly organize their experiences around being white but do not, except when attending schools with other self- and socially identified ethnoracial groups, develop distinct senses of their "whiteness" (Perry 2002). Instead, white students typically define "white" as "normal" (i.e., "race-neutral"; Perry 2002) and may consider themselves less vulnerable to the everyday injustices experienced by African American or Latino/a youth (Fine et al. 2003).

In a survey study of more than 18,000 Chicago public high school students, for example, Hagan, Shedd, et al. (2005) found that self-identified African American and Latino/a youth perceive themselves to be more vulnerable to and experience more discriminatory police contacts than white students. Other studies

\footnotetext{
${ }^{4}$ Our focus on ethnoracial self-identity is not intended to drive an ontological wedge between other important aspects of self-identity among youth, especially social class and gender. We accent ethnoracial self-identity because of its particular relevance for the rights domains we are studying.
} 
suggest similar patterns with respect to African American and Latino/a youths' expectations of discrimination by adults in official capacities: by teachers in schools (Rosenbloom \& Way 2004); by private security guards and police in public places, such as shopping malls (O'Dougherty 2006) or city streets (Fine et al. 2003); by police while driving a car (Lundman \& Kauffman 2003); or by prospective employers (Pager 2007).

The few studies on perceptions of rights among African American and Latino/a students regarding rights violations relevant to freedom of expression suggest parallel findings to those on discrimination (Bloemraad \& Trost 2006; Haney López 2003), with social movement research specifically suggesting that African American youth expect and experience intense repression of their rights to freedom of expression (Crenshaw 1988; Earl et al. 2003; McAdam 1988; Stockdill 2001). With respect to the experience of sexual harassment, multiple survey-based studies demonstrate its pervasiveness in secondary schools, although firm estimates of the influence of race and ethnicity on the experience of harassment are unavailable because of data collection and institutional constraints (see the review in V. Lee et al. 1996). Qualitative evidence, however, suggests that African American women and adult Latinas experience higher rates of perceived sexual harassment than white women in workplaces (Cortina 2001).

Hypothesis 3: African American and Latino/a youth perceive rights violations at higher rates than white youth.

Youth who self-identify as Asian Americans may be situated quite differently from African American or Latino/a youth. Although Asian Americans have suffered a long, collective history of discrimination and engaged in an intense striving for rights as a means for full membership in American society (Ancheta 2006; Motomura 2006), contemporary Asian American youth in schools are also socially constructed as a "model minority" that is assimilating or has assimilated into "mainstream" (read white) society via aggregate high academic achievement and subsequent career success (S. Lee 2009). This dynamic can lead to a conflicted self-identity--on the one hand, "flattering in comparison with stereotypes of other racial minorities," yet also dehumanizing-and may also lead to self-censure by Asian American students about their "own experiences and voices" regarding rights violations (S. Lee 2009:9). This self-censure may result in self-reports of rights violations among Asian American youth that approximate those among white youth. 
Hypothesis 4: Asian American youth perceive rights violations at rates similar to white youth.

\section{How Race Matters in Hypothetical Rights Mobilization}

As youth come to self-identify as African American or Latino/a, they can also become aware of the historical legacies of the "minority rights revolution" (Skrentny 2002), especially the civil rights movement. Within this legacy, schools played important roles both as vehicles for achieving and teaching about ethnoracial equality and justice. Throughout the 1960s and 1970s, fiscal and political support for education increased at every level of government, and ethnoracial justice became an important rationale for these efforts (Kirp 1982:197). As commonly taught in high school civics or history classes, this legacy is often organized around stories about the courage of individual African Americans (and Latinos/as in more inclusive versions) to challenge racial and ethnic injustice (Aldrige 2002; Dunn 2005; View 2004; e.g., the Denver Public School District's Alma Project curriculum, "Lessons in Courage: Martin Luther King, Rosa Parks, and Ruby Bridges" [B. Williams 2001], or online curricula, such as http://www.adl.org/education/rosa_parks/ sources-information or http://www.freechild.org/student_rights.htm). Although a recent national survey revealed high school seniors' knowledge of important historical events in American history to be rudimentary at best, 97 percent of the students surveyed could accurately identify Dr. Martin Luther King Jr. as "a historically significant figure" who challenged racist authority and led the civil rights movement (Hess 2008:9).

In these and similar curricula, Rosa Parks' refusal to move to the back of a segregated Montgomery, Alabama, city bus in 1955 or the first days of school integration in 1957 by small groups of African American students in Little Rock, Arkansas (the "Little Rock Nine"), are celebrated not only for their protagonists' courage, but also as the beginnings of waves of court cases that continued and extended the legacy of Brown and other landmark legal decisions to challenge the constitutionality of racial and ethnic segregation and discrimination across all spheres of American life (J. Williams \& Bond 1988). Stories of individual rights mobilization (in actuality embedded in formally organized collective action and social movements; Polletta 2006) have importantly become part of the "myth" about American "egalitarian possibilities of beleaguered minorities" (Scheingold 1974:78; see also Abrego 2008; Delgado \& Stefancic 2000). This myth, however, may not figure in the same ways in the collective consciousness of white youth, who may imagine legal rights not as part of the march toward social justice, but as a 
taken-for-granted element of law and order or, even more pervasively, as somewhat peripheral to their everyday lives (Scheingold 1974:78; Skrentny 2002). These orientations may be especially strong in white youth who define their "whiteness" as "normal," and hence perceptually removed from the social injustices experienced by nonwhite youth (Perry 2002).

So deeply can the myth of rights inhabit the legal consciousness of African Americans that Williams has argued, "To say that blacks never fully believed in rights is true; yet it is also true that blacks believed in them so much and so hard that we gave them life where there was none before" (P. Williams 2000:87). For Latinos'/as' legal consciousness, especially that of newly arrived immigrants, the mobilization of civil rights is at the core of escaping the status of "permanent foreigner" that, in turn, enables the recognition of social membership in U.S. society and the "pursuit of [individual and collective] projects without harassment and discrimination" (Young 2000:159; Abrego 2008; Gómez 2004). Thus, for African American and Latino/a youth, in contrast to white youth, the mobilization of formal law may occupy a much more salient place in their ideals about how social injustice should be handled.

Although taking quasi-legal action does not present the same barriers for youth as mobilizing formal law, African American, Latino/a, Asian American, and white youth may ideally view such actions as similar to formal legal action. This perception may occur because of the popular sense that the private legal order of quasilegal structures is fused with the public legal order (Edelman \& Suchman 1999) or simply because, from the perspective of youth, all institutionalized authority (whether law or not) points toward adult authority (Morrill \& Musheno, forthcoming).

Hypothesis 5: In response to hypothetical scenarios containing rights violations, African American and Latino/a youth are more likely than white youth to claim they would mobilize formal law or take quasilegal action.

The legacy of the civil rights movement has not figured as prominently in the legal consciousness of Asian Americans despite more than a century of discrimination, as well as individual and collective struggles for rights and social justice (Ancheta 2006; Motomura 2006). On the contemporary scene, Asian American legal consciousness, especially among youth, may be powerfully shaped by the pervasiveness of the "model minority" construct in American schools (S. Lee 2009). Asian American youth may draw on this construct (albeit with ambivalence or lament) as they define their own identities, thus leading away from formal law as a means of redress for social injustice. 
Hypothesis 6: In response to hypothetical scenarios containing rights violations, Asian American youth are less likely than white youth to claim they would mobilize formal law and take quasi-legal action.

\section{How Race Matters in Actual Rights Mobilization}

Against the backdrop of the heroic imagery of the civil rights movement, many African American and Latino/a youth face multiple barriers to actually mobilizing their rights. First, many African American and Latino/a youth, compared to white or Asian American youth, may face especially difficult financial and knowledge barriers to mobilizing formal law given lower aggregate income and educational attainment levels across African American, Latino/a, Asian American, and white households (Oliver \& Shapiro 2006).

Second, the long history of African American oppression and contemporary police surveillance in African American communities has created a pervasive and profound African American distrust of legal authorities (Anderson 1999; Nielsen 2004). African American youth socialization into this "cognitive landscape" (Sampson \& Bean 2006) is reinforced by aggregate police neglect of everyday problems in African American communities (Anderson 1999) and intense scrutiny of black youth when they venture into white or multiethnic contexts (Hagan, Hirschfield, et al. 2002; O'Dougherty 2006). This scrutiny has increased during the last generation as all youth have come under intensive surveillance with shifts in federal and local educational policy from concerns about access to education for socially disadvantaged groups to concerns about the "dangerousness" of such groups, especially African American youth (Ferguson 2000; Krisberg 2008; Kupchik 2009; Simon 2007:20731; Welch \& Payne 2010). As a result, African American youth, compared to white teens, may become resigned to the inability of law to redress the injustices they encounter (Bumiller 1988:61) and may be motivated to do nothing or take extralegal measures to respond to rights violations that also bolster their reputations among peers (Anderson 1999).

Latino/a youth experience some of the same collective distrust of legal and official school authorities and resignation as African Americans, but they are also embedded in the specter of concerns about citizenship and the potential for deportation from the United States. For Latino/a youth, not turning to formal law or taking quasi-legal action may therefore be rooted in collective anxieties and social stigma associated with actually being or being perceived as undocumented and living in the shadows of the "mainstream ... legal" society (Menjívar \& Bejarano 2003:126; Abrego 2008). Thus, 
Latino/a youth may be motivated as much by collective stigma as distrust of the law and other forms of official authority to do nothing or take extralegal action in response to situations they define as rights violations by peers or adults (Cintrón 2000; SánchezJankowski 2008).

The situation of Asian American youth, in the aggregate, may again suggest different mechanisms in play with respect to their responses to rights violations than that of African American or Latino/a youth. In particular, Asian American youth may be concerned about sullying the sometimes "flattering" model minority stereotype they experience or because school officials and other adults do not regard grievances by Asian American youth as serious, because their perception may be that Asian American youth are collectively "problem-free" compared to other ethnoracial groups, including white youth (S. Lee 2009). The pressure to conform to the problem-free stereotype is likely to lead Asian American youth to do nothing or to take extralegal actions in response to rights violations (Rosenbloom \& Way 2004).

For white youth, the situation is likely to be different still. Although the increased surveillance and security presence in schools has been pervasive throughout the United States (Kupchik 2009), it has been felt most keenly and disproportionately by African American and Latino/a youth (Kupchik 2009; Welch \& Payne 2010). Indeed, white youth are more likely than nonwhite youth to perceive law and official authority in public spaces as a form of "protection" rather than control, which may lead them to be less distrusting or fearful of, and more reliant on, legal and other official authority to redress rights violations (Fine et al. 2003).

Hypothesis 7: In response to actual rights violations, African American, Latino/a, and Asian American youth are less likely than white youth to report they took quasi-legal or formal legal actions in response to actual rights violations.

Hypothesis 8: In response to actual rights violations, African American, Latino/a, and Asian American youth will be more likely than white youth to report they did nothing or took extralegal action in response to actual rights violations.

\section{Methodological Procedures and Contexts}

We investigate the hypotheses above with surveys of students and in-depth interviews with students, teachers, and administrators in U.S. public, private (Catholic), and charter high schools in large 
metropolitan areas of California, New York, and North Carolina. ${ }^{5}$ We selected these three states in order to examine the operation of law in school life across three different state-level legal contexts.

\section{Study Design}

Within each state, we sought variation in school sector (public, public charter, and private) and the social composition of student bodies (principally by household income as indicated in the percentage of students eligible for free or reduced-price lunch under the National School Lunch Program). To the extent possible, we selected within each state four public schools (two each that served upper-/middle-income populations and two that served lower-income populations); two charter schools (one that served an upper-/ middle-income populations and one that served a lower-income population); and two private schools (one that served an upper-/ middle-income population and one that served a lower-income population). We chose Catholic schools as exemplars of private schools in the sample because they are the modal type of private school in the United States and because they have similar supraschool governance structures to public schools (e.g., dioceses and archdioceses vs. school districts). In six of the eight schools within each state, we conducted surveys of students, teachers, and administrators. In the remaining two schools (one each that served an upper-/middle-income population and one that served primarily a lower-income population) in both California and New York, we conducted in-depth interviews and surveyed students, teachers, and administrators toward the end of the data collection period. In North Carolina, due to access problems, we conducted in-depth interviews only at an upper-/middle-income school.

\section{State Legal Contexts and School Sites}

Each of the states in the study is subject to a uniform set of federal statutes and Constitutional principles with respect to education but nonetheless exhibits differences in particular rules and procedures, especially surrounding discipline and corporal punishment. California has long prohibited corporal punishment, whereas New York formally permits it, although it is banned in New York City. By contrast, North Carolina educational code permits corporal punishment as long as it is done "without malice" and to further "educational goals" (Berk 2007:24). All three states also have explicit provisions that reinforce civil rights protections

\footnotetext{
${ }^{5}$ Data on which this article is based were collected during 2006-2008.
} 
against discrimination, but only California and New York have protections for "non-citizen" students (Berk 2007:7).

Evidence of campus security could be found at all our study sites. At each of the public school sites, private security guards could be found patrolling the hallways on any given day, and at our lower-income schools, police officers were often present. Catholic schools, with the exception of North Carolina, had guards posted at campus entrances but not elsewhere. The California and New York charter schools exhibited a mixture of characteristics: Lowerincome charters had guards (but not police), while middle-income charters posted guards at entrances, but not inside campuses. ${ }^{6}$

\section{Surveys}

At each of the schools in the sample, we surveyed the entire ninth and eleventh grade classes, focusing on youths as they entered high school and toward the end of their high school careers. The surveys focused on perceptions of law, rights, and rights violations at the individual level, with components including (1) demographics (including sex, age, race, ethnicity, social background, status with respect to federally recognized special needs, and educational/employment position-such as track placement or work assignment and job tenure); (2) current understandings and past experiences of law and legal structures (including perceptions of fairness); (3) ideas about law, legal structures, and institutional authority; (4) previous experiences with rights violations involving discrimination, harassment, discipline, and freedom of speech/ assembly; and (5) a set of hypothetical scenarios (one per respondent) representing the same areas of rights violations as in the section about past experiences.

With respect to race and ethnicity, we asked students, "How do you identify your ethnicity or ancestry, that is, what do you call yourself?" and offered these categories: White/Anglo, African American/Black, Hispanic/Latino/a, American Indian, Asian American/Pacific Islander, Arab American, mixed ethnicity, or other. ${ }^{7}$ We based questions about rights violations in part from the Civil Litigation Research Project (CLRP; Kritzer 1980-81; Miller \& Sarat

6 The public schools in the study were larger (ranging from 1,400 to 2,300 students) than either the Catholic (ranging from 400 to 700 students) or charter schools (ranging from 200 to 800 students). The physical plants of our public school sites also varied, from schools serving primarily lower- or middle-income students occupying multiple floors of large, remodeled office buildings in California and New York to crumbling, smaller campuses serving lower-income students in California to spacious, college-like campuses serving middle- and upper-income students in California and North Carolina.

7 We recognize the measurement limitations of our categorical scheme (see the discussion in T. Lee 2009). At the same time, our measurement strategy is consonant with our theoretical interests in ethnoracial identity and is a standard measurement strategy. 
1980-81) and qualitative studies of legal mobilization and consciousness among adults and youth (Albiston 2005; Ewick \& Silbey 1998; Fuller et al. 2000; Morrill, Yalda, et al. 2000). Respondents were asked to check off any of the following situations they had experienced: peer harassment, discrimination, freedom of expression, sexual harassment, and disciplinary problems by a teacher or administrator. If respondents checked off any of these items, they were then asked to indicate which of the incidents they checked was the most "significant" or "important," and how they handled the situation using a list of items we classified as falling into one of our four mobilization categories (formal legal, quasi-legal, extralegal, or doing nothing). If respondents did not check off any actual experiences, they could proceed directly to the last section of the survey containing a hypothetical scenario.

\section{In-Depth Interviews}

Socially diverse teams of graduate and undergraduate students led by three of the four authors of this article conducted in-depth interviews of youth $(n=86)$, teachers $(n=36)$, and administrators $(n=9)$. We selected respondents purposively to represent the demographics and diverse experiences of youth and teachers on each campus, and we interviewed the principal at each site plus, where possible, an assistant principal in charge of discipline.

Each youth interview lasted between 30 minutes and two hours, was taped, and contained a tripartite structure: an opening section on respondents' general impressions of their schools, the informal social organization of their peers, and demographics (including how they identified themselves ethnically); a second section focused on each informant's knowledge and experiences of trouble and problems on campus; and a final part on informants' impressions of formal rules and rights on campus. Each teacher and administrator interview had the same structure, except that the first section included questions on work history and impressions of the student body at their school, the middle section included questions about "typical" problems and disputes encountered on campus, and the last section included questions about administrative and union relations in the teacher interviews, and union and district relations in the administrator interviews. The interview structure thus combined open-ended techniques used effectively in previous studies of informal disputing in organizations (e.g., Morrill 1995) and legal consciousness (e.g., Ewick \& Silbey 1998), with more explicit foci on school rules and rights.

Our analysis of the interview data proceeded in two phases. First, SRP team members read through all the interview transcripts as "data sets" (Emerson et al. 1995). We discussed our readings at 
multiple meetings with the entire SRP team during which we inductively developed initial qualitative coding categories via an "open coding" process (Lofland et al. 2005) that also drew on categories from our survey so that we could triangulate our findings across multiple data sets and interlace our interview and survey findings in write-ups. Second, we refined our initial codes and developed a master qualitative coding scheme using Atlas.ti to code each of the qualitative data sets from California, New York, and North Carolina. Because of the size of the California data set, the California team coded its own transcripts and the North Carolina and New York teams collaborated on coding their data sets. To enhance the cross-team reliability of our coding, we selected two extended, representative excerpts of transcripts from each state and had all SRP members participating in the qualitative analysis code them. We then compared our coding across teams and found high levels of interpretive consistency.

\section{Response Rates and Sample Characteristics}

The student response rates across schools ranged from 61 to nearly 100 percent, which resulted in a sample of 5,461 students. As can be seen in Table 1, nonwhite students comprised just under half the sample, with Latino/a students the largest among this group (17.4 percent), followed by African American students (13.1 percent), those students who self-identified as other (10.7 percent), and Asian American students ( 4.7 percent). ${ }^{8}$ As a proxy for socioeconomic status, we used parental education: More than three-quarters of students reported that either their mother's or father's education extended beyond high school. With respect to grade level, our sample was slightly skewed toward younger students (59 percent were ninth graders and 41 percent were eleventh graders), slightly more than two-thirds of respondents reported living in a two-parent household (69.7 percent), a small percentage reported being disabled ( 4.8 percent), and nearly all students reported being citizens (96.2 percent). The vast majority of our students attended public or Catholic schools (owing to typically small enrollments in public charter schools). The largest proportion of the sample came from California (39.2 percent), with just over a third from North Carolina (33.6 percent) and approximately one quarter from New York (27.2 percent).

\section{Multivariate Strategy}

To estimate the relationships between the four types of legal mobilization and self-identified ethnoracial category, we estimated

\footnotetext{
8 The small numbers of students who self-identified as Arab American, Native American, and multiethnic were dropped from the analysis.
} 
Table 1. Student Descriptives

\begin{tabular}{|c|c|c|}
\hline Variables & Percentage & S.E. \\
\hline \multicolumn{3}{|l|}{ Individual Characteristics } \\
\hline Male & 0.442 & 0.031 \\
\hline African American & 0.131 & 0.039 \\
\hline Latino/a & 0.174 & 0.044 \\
\hline Asian & 0.047 & 0.012 \\
\hline Other & 0.107 & 0.015 \\
\hline Parental education, some college & 0.144 & 0.020 \\
\hline Parental education, bachelor's degree & 0.299 & 0.009 \\
\hline Parental education, graduate degree & 0.377 & 0.048 \\
\hline l lth Grade & 0.410 & 0.021 \\
\hline Two parent household & 0.697 & 0.039 \\
\hline Disabled & 0.048 & 0.004 \\
\hline Citizen & 0.962 & 0.005 \\
\hline Perceived past rights violations & 0.517 & 0.019 \\
\hline \multicolumn{3}{|l|}{ School Characteristics } \\
\hline Public & 0.539 & 0.132 \\
\hline Catholic & 0.406 & 0.133 \\
\hline Charter & 0.055 & 0.031 \\
\hline Northeast & 0.272 & 0.109 \\
\hline South & 0.336 & 0.131 \\
\hline West & 0.392 & 0.127 \\
\hline \multicolumn{3}{|l|}{ Dependent Variables } \\
\hline \multicolumn{3}{|l|}{ Hypothetical Incident } \\
\hline Do nothing & 0.154 & 0.009 \\
\hline Extra-legal & 0.794 & 0.010 \\
\hline Quasi-legal & 0.312 & 0.011 \\
\hline Formal legal & 0.085 & 0.008 \\
\hline \multicolumn{3}{|l|}{ Past Incident } \\
\hline Did nothing & 0.193 & 0.014 \\
\hline Extra-legal & 0.763 & 0.014 \\
\hline Quasi-legal & 0.214 & 0.009 \\
\hline Formal legal & 0.032 & 0.007 \\
\hline $\mathbf{N}$ & 5,461 & \\
\hline
\end{tabular}

logit models. In a baseline model, we controlled for a number of individual and contextual characteristics. We based our decision to control for individual-level variables as a result of findings from previous research. First, previous research demonstrates that gender can influence legal mobilization in workplaces in response to discrimination and harassment net of other factors (Hoffman 2003; Marshall 2003). Second, we used parental education as a proxy for material and knowledge-based resources in households because such resources have been demonstrated in previous research to influence legal mobilization and socialization (e.g., Galanter 1974; Lareau 2003; Mayhew \& Reiss 1969; Merry 1990). Third, we controlled for U.S. citizenship because of the possibility that being documented or undocumented might affect the likelihood of mobilizing law net of ethnoracial category (Abrego 2008; Menjivar \& Bejarano 2003). Likewise, one's sense of being disabled may be related to rights consciousness and the perception of law as a viable response to rights violations (Engel \& Munger 2003). Finally, 
following standard practices in education research, we controlled for type of household (single or two-parent household) and grade level (Arum 2003). Our contextual controls included type of school (public, Catholic, and charter) and state (California, New York, and North Carolina).

In a second model, we included the respondent's experience with actual (past) rights violations as a control because experiences with injustice may alter perceptions of the efficacy of law for redressing rights violations (Bumiller 1988) and the likelihood of mobilization (Fuller et al. 2000). We ran separate logits for doing nothing and for each of the three types of mobilization independently. Thus, students could report that they would take one or several paths (i.e., extralegal, quasi-legal, and formal legal) to mobilize rights. We adjusted standard errors for school-level clustering.

\section{Rights Violations and Legal Mobilization in Schools}

The 51.7 percent rate of rights violations among youth in our sample was higher than self-reported rights violations in the only previous national random survey of legal mobilization by adults in CLRP, which reported an overall rate of 41.6 percent for all grievances (including discrimination in the workplace, consumer complaints, and community problems; Miller \& Sarat 1980-81). Other studies report grievance rates of 20 to 35 percent for consumer problems (Best \& Andreasen 1977; King \& McEvoy 1976; Warland et al. 1975), 60 percent for "low-income" consumer problems (Caplovitz 1963), and 45 percent for used car problems (McNeil et al. 1979).

\section{Legal Mobilization and Youth}

The patterns in Table 1 generally support Hypothesis 1 (taking extralegal action in response to a hypothetical rights violation): The vast majority of youth (79.4 percent) reported that they would respond to a hypothetical rights violation by taking extralegal action, followed by some sort of quasi-legal action (31.2 percent), doing nothing (15.4 percent), and taking formal legal action (8.5 percent) ${ }^{9}$ In support of Hypothesis 2 (taking extralegal action in response to an actual rights violation), the vast majority (76.3 percent) of the students who reported actual rights violations also reported taking extralegal action, followed by engaging in quasilegal action (21.4 percent), doing nothing (19.3 percent), and

9 The total percentages do not add up to 100 percent for categories other than "do nothing" because respondents could choose more than one response. 
taking formal legal action (3.2 percent). Indeed, fewer than 5 percent of students actually pursued any formal legal action at all in response to rights violations.

Youths' everyday understandings of the constraints they face in mobilization processes were evident throughout our qualitative interview data, as illustrated by this self-identified "Dominican" female senior regarding punishment in a New York school:

Interviewer: What rights do you think you have when you're facing punishment by a teacher or an administrator?

Student: Well I think that as long as they have to hear what you have to say and then at least consider it, then I think that-I mean, I know I don't have that many rights. I don't. The authority, I can't do anything. I'm 17 years old. I'm a minor, I don't have anything.

In this excerpt, the student began to assert that she did have rights ("as long as they have to hear what you have to say and then at least consider it") that spoke to due process, but then denied she could actually use those rights to address "authority" as it was exercised against her because of her age ("I'm a minor, I don't have anything").

While some youths lapse into resignation and inaction in response to rights violations, a more prevalent pattern in our qualitative data (consistent with our survey data) was mobilizing rights via extralegal action. Consider this example from a senior at a California school who identified himself as "mixed Latino/a, Asian, and white":

Well, of course there's the rights that have to do with American law and the right of free speech.... All those rights here, you know, are recognized in some way ideally.... See, with the teachers, it's usually the students talk[ing] amongst themselves about the teacher. [Students] don't go out and tell on them or anything. They're all like "Oh, this teacher-he's racist or something." They're not going to go to an authority and tell somebody they're racist or anything. They just kind of say it amongst themselves or do something on their own.... Kids don't have much power compared to adults ... but they know how to get back at a teacher if they want to ... make their classrooms hell.

Like the informant from New York, this respondent claimed that his school generally "recognizes" rights in "American law" but then observed that students did not "have ... power" relevant to adults, rarely mobilizing their rights formally when faced with rights violations. Instead, they resorted to extralegal action ("say it amongst themselves or do something on their own"). Youth can feel powerless in trying to exercise formal channels to handle problems with adults in their schools, but powerful outside of those 
channels. Some of their actions in this regard tap into the myth of rights (Scheingold 1974) but more typically draw on local knowledge about how school order is maintained as a way to frame and act against official authority deemed unjust (e.g., McFarland 2004). In this way, power and authority in schools are relational as is the basis for youth resistance to adult authority (Ewick \& Silbey 2003).

With respect to peers, extralegal tactics are also the first line of action, as illustrated in the following interview excerpt from a selfidentified "white" male senior at a middle-/upper-income school in California. The youth was responding to questions about whether he ever had "trouble" with students, and how he handled it:

I mean like it's kinda embarrassing. I had this girl, like she was... stalking me. Everywhere I went, there she was. I mean, dude, she was a trip. Now I'm not going to go to some counselor [or]. security dude and say "What the hey, there's this chick after me." ... I talked with my friends a lot and they said, "Whoa dude, you gotta right not to have her in your face like that." So I went to her and told her to cool it. Get outta my face.... It worked for a while, then she, like was there again.... I changed my schedule ... she transferred like the next term.

Although this pattern did not generalize to every interpersonal peer conflict we learned about through our informants, it was typical among youth in our data sets: a recognition of a problem or trouble with a peer ("I had this girl ... stalking me"), consultation with trusted peers ("talked with my friends"), remedial action taken with the offending party in an attempt to alter her behavior ("went to her ... told her to cool it"), avoidance ("changed my schedule"), and then resolution only when the offending party exited the scene ("she transferred"). These tactics are also consistent with a number of studies on the social dynamics of interpersonal conflict management (Emerson 2008). What is interesting is the explicit sense given in the interview of mobilizing rights, not through the law or a quasi-legal structure, but via extralegal means. That is, rights can provide a rationale for one's actions even in the midst of operating outside official authority or law.

\section{Rights Violations and Ethnoracial Identity}

Quantitative evidence for the relationships between ethnoracial self-identity and perceived rights violations (Hypotheses 3 and 4) can be found in Table 2. In support of Hypothesis 3, African Americans '(59.1 percent; $p<0.01$ ), Latinos/as (53.1 percent; $p<0.01$ ), and students who identified as other (58.6 percent; $p<0.01$ ) all reported higher overall rates of perceived rights 
Table 2. Perceived Past Rights Violations by Race

\begin{tabular}{|c|c|c|c|c|c|c|c|c|c|c|}
\hline \multirow[b]{2}{*}{ Variables } & \multicolumn{2}{|c|}{ White } & \multicolumn{2}{|c|}{$\begin{array}{l}\text { African } \\
\text { American }\end{array}$} & \multicolumn{2}{|c|}{ Latino/a } & \multicolumn{2}{|c|}{ Asian } & \multicolumn{2}{|c|}{ Other } \\
\hline & \multicolumn{2}{|c|}{$\%$} & \multicolumn{2}{|c|}{$\%$} & \multicolumn{2}{|c|}{$\%$} & \multicolumn{2}{|c|}{$\%$} & \multicolumn{2}{|c|}{$\%$} \\
\hline \multirow{8}{*}{$\begin{array}{l}\text { Perceived Individual Rights Violations } \\
\text { Discriminated Against by a Teacher or Administrator } \\
\text { Denied Services for Special Needs } \\
\text { Inappropriate Sexual Language or Behavior by a Teacher } \\
\text { Inappropriate Sexual Language or Behavior by a Student } \\
\text { Teacher Did Not Follow Correct Disciplinary Procedure } \\
\text { Any Perceived Individual Rights Violations }\end{array}$} & & & & & & & & & & \\
\hline & 0.185 & & $0.337^{* *}$ & & $0.282^{* *}$ & & $0.332^{* * *}$ & & $0.272^{* *}$ & \\
\hline & 0.068 & & 0.079 & & 0.071 & & 0.042 & & 0.082 & \\
\hline & 0.108 & & 0.093 & & $0.079^{* *}$ & & $0.033^{* * *}$ & & 0.137 & \\
\hline & 0.254 & & 0.210 & & 0.226 & & 0.208 & & 0.268 & \\
\hline & 0.183 & & 0.195 & & 0.172 & & $0.141^{*}$ & & 0.193 & \\
\hline & 0.480 & & $0.591^{* *}$ & & $0.531^{* *}$ & & 0.498 & & $0.586^{* \star *}$ & \\
\hline & Mean & S.E. & Mean & S.E. & Mean & S.E. & Mean & S.E. & Mean & S.E. \\
\hline \multirow{2}{*}{$\begin{array}{l}\text { Average Number of Perceived Individual Rights Violations } \\
\mathrm{N}\end{array}$} & 0.799 & 1.076 & $0.913^{* * *}$ & 1.003 & 0.830 & 1.015 & 0.755 & 0.928 & $0.953^{\star \star}$ & 1.097 \\
\hline & 2,762 & & 668 & & 886 & & 241 & & 548 & \\
\hline
\end{tabular}


violations than did white students (48.0 percent). In support of Hypothesis 4, Asian American students' rate of perceived rights violations (49.8 percent) was not significantly different from that of white students.

The disaggregation of these results by type of rights violation in Table 2 reveals a more complex picture. ${ }^{10}$ All nonwhite students reported higher rates of teacher and administrator discrimination against them than white students (18.5 percent), with African American (33.7 percent; $p<0.01$ ) and Asian American students (33.2 percent; $p<0.01$ ) reporting the highest rates, followed by Latino/a students $(28.2$ percent; $p<0.01)$ and students who selfidentified as other $(27.2$ percent; $p<0.01)$. Few students reported being denied services for special needs, and there were not any significant differences across racial and ethnic categories. Latino/a (7.9 percent; $p<0.01$ ) and Asian American (3.3 percent; $p<0.01$ ) students reported significantly lower rates than white students (10.8 percent) of inappropriate sexual language or behavior by teachers. Students of different racial and ethnic groups reported similar rates of inappropriate sexual language or behavior by peers (ranging between 25.4 percent for white students and 20.8 percent for Asian American students). Finally, students of different racial and ethnic groups reported similar rates of perceived rights violations with respect to teachers not following the correct (due process) disciplinary procedure (ranging from 18.3 percent for white students to 19.5 percent for African American students), save for Asian American students, who reported lower rates than did white students (14.1 percent; $p<0.05$ ).

Excerpts from in-depth interviews with youth about situations they defined as rights violations illuminate these patterns and underscore how ethnoracial identity organizes their interpretations. In the representative excerpts below, students from a California campus recounted their experiences in portions of in-depth interviews that covered problems with teachers. In the first excerpt, a self-identified "Mexican" female junior discussed her perceptions of discrimination in a teacher's evaluation of a writing assignment. In the second excerpt, a self-identified "mostly white and some Italian" female junior discussed her sense of discrimination on campus:

Oh, yeah with grades.... Like, I would look at my paper and a friend's paper who's Anglo, and I would do the same thing and she [the teacher] wouldn't give me full credit for it, and oh, look what I did here - it's the same as her.... There was definitely discrimination.... It's something you feel every day about

10 Note that the subtypes of rights violations in Table 2 do not add up to 100 percent because survey respondents could check more than one type of violation. 
because of what you look like, who you are, where you come from.... There's this sense that you, you can't take these classes, like whatever, you're not smart because you're Mexican or whatever.

$* * *$

I mean, there's this one white kid that you can tell is kind of-he discriminates against like Mexicans. But it's hard to think of lots of problems like that from students or teachers... Like maybe if I was black or Mexican or something, it might be different ... From my perspective, there really isn't a big problem that I know about. I just don't see it.

In the first excerpt, self-identity intersected with what the student perceived as a stigmatized social identity (i.e., how the social category the student identifies with is perceived by others; Engel \& Munger 2003). The context is an AP English class from which she believed "Mexicans" were excluded because of stereotypes about their intelligence. She also suggested that her experience of discrimination was an everyday occurrence and related it to who she is and, as she noted later in the interview, her country of origin ("where you come from"; she immigrated to the United States from Mexico with one of her parents when she was a young child). The second student's experience contrasts sharply with the first. The respondent spoke of a seemingly isolated case of peer discrimination against "Mexicans" and, interestingly, referenced how her self-identity might modify her sense of what goes on at her campus if she were "Black" or "Mexican." From her vantage point as a white youth, she did not "see" discrimination by teachers, more generally, as a "problem" on her campus.

A very different sense of discrimination emerges from the perspective of a self-identified Thai and Vietnamese female junior on the same campus. Her experiences were not grounded in negative expectations by teachers and other adults but by heightened, positive expectations about the normativity of her behavior:

At home and in school it's the same, you have to be perfect. I never give anyone any trouble. Just mellow. I mean, like at home I get disciplined a lot more than I would here [in school] ... because I am not allowed to do a lot of stuff anyways. Having, being so perfect all the time, it's difficult to believe bad stuff is happening to you, talk about it even ... like when that kid who was staring at my feet in class and touching my bare feet in class when I wore sandals ... I didn't do anything about it for a long time.... But like I think that a lot of teachers or counselors don't think things like that occur to an Asian. Like nothing deviant is supposed to happen with the whole super Asian thing.... Maybe that's why my counselor - I mean, I left him messages-and it took forever for him to get a hold of me. 
The reference in this excerpt is to recurring sexual harassment in which a male peer would stare at and touch the respondent's bare feet in unwanted ways in class. In this excerpt, we find evidence for the model minority stereotype working in multiple ways. On the one hand, the respondent recounted normative pressures at home and in school for her to be "perfect" as an "Asian." On the other hand, these pressures led to her disbeliefs and difficulties talking about her experiences being harassed (self-censoring). She recounted that she "didn't do anything" about the incidents for "a long time," but when she did attempt to mobilize her "counselor" to address the situation she believed that what she called "the whole super Asian thing" played a role in his lack of responsiveness.

\section{Legal Mobilization and Ethnoracial Identity}

\section{Bivariate Analyses}

The patterns in Table 3 partially support Hypothesis 5 (that in response to hypothetical rights violations, African American and Latino/a students claim they would mobilize law and take quasi-legal actions at higher rates than white students) but do not support Hypothesis 6 (that in response to hypothetical rights violations, Asian American youth are less likely than white youth to claim they would mobilize formal law or take quasi-legal actions). More African American students (10.6 percent; $p<0.05)$ than white students ( 7.1 percent) claimed they would mobilize law in response to a hypothetical rights violation, but nearly as many Asian American students (7.1 percent) as Latino/a (8.7 percent) and white students ( 8.7 percent) claimed they would mobilize law or take quasi-legal action (2.7 percent for Asian American youth vs. 3.0 percent for white youth).

The results in Table 3 also partially support Hypothesis 7 (that African American, Latino/a, and Asian American youth are less likely than white youth to report taking formal legal or quasi-legal actions in response to actual rights violations) and Hypothesis 8 (that African American, Latino/a, and Asian American youth are more likely than white youth to report taking extralegal action or doing nothing in response to actual rights violations). Latino/a youth reported mobilizing law at a lower rate in response to actual rights violations ( 1.6 percent; $p<0.01)$ than white students $(4.3$ percent). African American and Asian students, by contrast, were no more likely than white students to mobilize law in response to an actual rights violation. African American students were also more likely than white students (19.9 percent vs. 16.2 percent; $p<0.05)$ to report doing nothing in response to an actual rights 
Table 3. Mediating and Dependent Variables by Race

\begin{tabular}{|c|c|c|c|c|c|c|c|c|c|c|}
\hline \multirow[b]{2}{*}{ Variables } & \multicolumn{2}{|c|}{ White } & \multicolumn{2}{|c|}{ African American } & \multicolumn{2}{|c|}{ Latino/a } & \multicolumn{2}{|c|}{ Asian } & \multicolumn{2}{|c|}{ Other } \\
\hline & $\%$ & $S . E$. & $\%$ & S.E. & $\%$ & S.E. & $\%$ & S.E. & $\%$ & S.E. \\
\hline \multicolumn{11}{|l|}{ Mediating Variable } \\
\hline Perceived past violations & 0.480 & 0.025 & $0.591^{* *}$ & 0.019 & $0.530^{*}$ & 0.020 & $0.498^{*}$ & 0.041 & $0.586^{* *}$ & 0.030 \\
\hline \multicolumn{11}{|l|}{ Dependent Variables } \\
\hline \multicolumn{11}{|l|}{ Hypothetical Incident } \\
\hline Do nothing & 0.153 & 0.010 & 0.139 & 0.013 & 0.181 & 0.019 & 0.161 & 0.027 & 0.120 & 0.019 \\
\hline Extra-legal & 0.800 & 0.012 & 0.801 & 0.016 & $0.755^{*}$ & 0.022 & 0.807 & 0.034 & 0.824 & 0.020 \\
\hline Quasi-legal & 0.304 & 0.014 & 0.318 & 0.016 & 0.329 & 0.026 & 0.271 & 0.026 & 0.339 & 0.018 \\
\hline Formal legal & $0.07 \mathrm{I}$ & 0.010 & $0.106^{*}$ & 0.017 & 0.087 & 0.009 & 0.087 & 0.018 & $0.108^{* * *}$ & 0.011 \\
\hline \multicolumn{11}{|l|}{ Past Incident } \\
\hline Did nothing & 0.199 & 0.014 & $0.162^{*}$ & 0.015 & 0.209 & 0.026 & 0.177 & 0.038 & 0.207 & 0.036 \\
\hline Extra-legal & 0.760 & 0.017 & 0.790 & 0.018 & 0.744 & 0.025 & 0.796 & 0.030 & 0.737 & 0.036 \\
\hline Quasi-legal & 0.211 & 0.011 & 0.234 & 0.018 & 0.218 & 0.027 & 0.195 & 0.035 & 0.188 & 0.023 \\
\hline Formal legal & 0.043 & 0.013 & 0.024 & 0.005 & $0.016^{* *}$ & 0.004 & 0.027 & 0.013 & 0.033 & 0.011 \\
\hline $\mathrm{N}$ & 2,762 & & 668 & & 886 & & 241 & & 548 & \\
\hline
\end{tabular}

$* p<.05, * *_{p}<.01,{ }^{* * *} p<.001$.

Note: Significant differences between minority and white students are noted with asterisks next to group means. 
violation, which may relate to the resignation felt especially by African American youth with respect to the everyday possibilities for social justice from formal legal or quasi-legal action.

\title{
Multivariate Analyses of Responses to Hypothetical Rights Violations
}

Our multivariate analyses in Table 4 provide a more sensitive examination of our two hypotheses regarding responses to hypothetical rights violations. In partial support of Hypothesis 5, African American youth were more likely to claim they would mobilize law in response to hypothetical rights violations in the baseline model $(0.539 ; p<0.05)$. However, this result lost statistical significance in the second model that takes into account actual (past) experiences with perceived rights violations. It may be that the high rates of African American students who have experienced rights violations (especially discrimination) compels them to be more skeptical of the myth of rights and resigned to navigate through everyday rights violations without the law or quasi-legal action. This finding is consistent with Bumiller's (1988) argument that African American persons' experiences with injustice mediate their claims about what they would do in response to a rights violation. This quantitative result is also consistent with a typical observation drawn from our in-depth interviews with African American and Latino/a youth. Listen to this self-identified, "mixed Black-Mexican" senior male discuss learning about versus actually mobilizing rights on his California campus in response to a question about what rights he thought he had in school:

\begin{abstract}
Rights, rights, rights. We learn all about rights in school. You like listen to the speeches in class - hear the stories, Rosa on the bus, MLK, Caesar [Chavez] in the fields. ... It's inspirational. I'm glad they did what they did, stood up for our, our rights and all. You wanna stand up for [one's rights] too. It's who I wanna be.... Like, like my mom has a picture of MLK on the wall and she always said to stand up for stuff.... What happens every day if you're black or Mexican - that gets you thinking different.... There's prejudice, racist stuff all the time. They always watching you, the guards, teachers, you know.... Sometimes it seems that what [civil rights figures] did ... that what they did don't matter today. Maybe I can't be like that. I don't know.
\end{abstract}

The paradox of rights and race is vividly expressed in this youth's voice. The narrative history of heroic acts and heroes of the civil rights movement is, as the youth observes, "inspirational," and it is taught both in the class and at home. The courage to "stand up" for these ideals, so the respondent notes, is how he wants to define his identity. But the everyday realities, including constant surveillance 
Table 4. Models Estimating the Likelihood of Taking Action Against a Hypothetical Rights Violation

\begin{tabular}{|c|c|c|c|c|c|c|c|c|}
\hline \multirow[b]{2}{*}{ Variables } & \multicolumn{2}{|c|}{ Do Nothing } & \multicolumn{2}{|c|}{ Extra Legal } & \multicolumn{2}{|c|}{ Quasi Legal } & \multicolumn{2}{|c|}{ Formal Legal } \\
\hline & $\begin{array}{c}\text { Baseline } \\
\text { Model }\end{array}$ & $\begin{array}{c}\text { Baseline } \\
\text { Model+ Perceived } \\
\text { Past Rights } \\
\text { Violations }\end{array}$ & $\begin{array}{c}\text { Baseline } \\
\text { Model } \\
\end{array}$ & $\begin{array}{c}\text { Baseline } \\
\text { Model+Perceived } \\
\text { Past Rights } \\
\text { Violations } \\
\end{array}$ & $\begin{array}{c}\text { Baseline } \\
\text { Model }\end{array}$ & $\begin{array}{c}\text { Baseline } \\
\text { Model+Perceived } \\
\text { Past Rights } \\
\text { Violations } \\
\end{array}$ & $\begin{array}{c}\text { Baseline } \\
\text { Model }\end{array}$ & $\begin{array}{c}\text { Baseline } \\
\text { Model+Perceived } \\
\text { Past Rights } \\
\text { Violations } \\
\end{array}$ \\
\hline \multicolumn{9}{|l|}{ Individual Characteristics } \\
\hline Male & $\begin{array}{c}0.651^{\text {}} \\
(0.100)\end{array}$ & $\begin{array}{c}0.652 \\
(0.100)\end{array}$ & $\begin{array}{c}-0.550 * \\
(0.080)\end{array}$ & $\begin{array}{c}-0.551^{* * *} \\
(0.080)\end{array}$ & $\begin{array}{c}-0.394 * \\
(0.085)\end{array}$ & $\begin{array}{c}-0.391 \\
(0.084)\end{array}$ & $\begin{array}{c}0.121 \\
(0.131)\end{array}$ & $\begin{array}{c}0.132 \\
(0.132)\end{array}$ \\
\hline African American & $\begin{array}{c}-0.03 \\
(0.109)\end{array}$ & $\begin{array}{c}-0.034 \\
(0.113)\end{array}$ & $\begin{array}{c}-0.029 \\
(0.104)\end{array}$ & $\begin{array}{c}-0.021 \\
(0.107)\end{array}$ & $\begin{array}{c}-0.086 \\
(0.134)\end{array}$ & $\begin{array}{r}-0.120 \\
(0.135)\end{array}$ & $\begin{array}{r}0.539^{*} \\
(0.252)\end{array}$ & $\begin{array}{c}0.479 \\
(0.254)\end{array}$ \\
\hline Latino/a & $\begin{array}{c}0.247^{*} \\
(0.119)\end{array}$ & $\begin{array}{c}0.245^{4} \\
(0.120)\end{array}$ & $\begin{array}{r}-0.255^{4} \\
(0.107)\end{array}$ & $\begin{array}{r}-0.252^{*} \\
(0.109)\end{array}$ & $\begin{array}{c}0.011 \\
(0.116)\end{array}$ & $\begin{array}{c}0.002 \\
(0.117)\end{array}$ & $\begin{array}{c}0.325 \\
(0.110)\end{array}$ & $\begin{array}{c}0.302^{* *} \\
(0.111)\end{array}$ \\
\hline Asian & $\begin{array}{c}0.211 \\
(0.196)\end{array}$ & $\begin{array}{c}0.210 \\
(0.196)\end{array}$ & $\begin{array}{r}-0.052 \\
(0.204)\end{array}$ & $\begin{array}{c}-0.051 \\
(0.204)\end{array}$ & $\begin{array}{r}-0.258^{*} \\
(0.112)\end{array}$ & $\begin{array}{r}-0.264^{*} \\
(0.112)\end{array}$ & $\begin{array}{c}0.251 \\
(0.191)\end{array}$ & $\begin{array}{c}0.245 \\
(0.194)\end{array}$ \\
\hline Other & $\begin{array}{c}-0.176 \\
(0.170)\end{array}$ & $\begin{array}{c}-0.179 \\
(0.170)\end{array}$ & $\begin{array}{c}0.073 \\
(0.115)\end{array}$ & $\begin{array}{c}0.079 \\
(0.115)\end{array}$ & $\begin{array}{c}0.056 \\
(0.100)\end{array}$ & $\begin{array}{c}0.037 \\
(0.100)\end{array}$ & $\begin{array}{c}0.593^{4} \\
(0.141)\end{array}$ & $\begin{array}{l}0.541^{* * *} \\
(0.138)\end{array}$ \\
\hline Parental education, some college & $\begin{array}{r}-0.089 \\
(0.167)\end{array}$ & $\begin{array}{r}-0.089 \\
(0.167)\end{array}$ & $\begin{array}{c}0.138 \\
(0.172)\end{array}$ & $\begin{array}{c}0.138 \\
(0.171)\end{array}$ & $\begin{array}{c}0.115 \\
(0.103)\end{array}$ & $\begin{array}{c}0.116 \\
(0.102)\end{array}$ & $\begin{array}{c}0.064 \\
(0.183)\end{array}$ & $\begin{array}{c}0.067 \\
(0.183)\end{array}$ \\
\hline Parental education, bachelor's degree & $\begin{array}{r}-0.286^{*} \\
(0.127)\end{array}$ & $\begin{array}{r}-0.285^{*} \\
(0.127)\end{array}$ & $\begin{array}{c}0.322^{* *} \\
(0.101)\end{array}$ & $\begin{array}{l}0.319^{* *} \\
(0.101)\end{array}$ & $\begin{array}{c}0.055 \\
(0.116)\end{array}$ & $\begin{array}{c}0.062 \\
(0.114)\end{array}$ & $\begin{array}{c}-0.256 \\
(0.159)\end{array}$ & $\begin{array}{c}-0.235 \\
(0.161)\end{array}$ \\
\hline Parental education, graduate degree & $\begin{array}{c}-0.339^{* *} \\
(0.126)\end{array}$ & $\begin{array}{c}-0.338^{* *} \\
(0.125)\end{array}$ & $\begin{array}{c}0.320^{* *} \\
(0.124)\end{array}$ & $\begin{array}{r}0.318^{*} \\
(0.124)\end{array}$ & $\begin{array}{c}0.207 \\
(0.117)\end{array}$ & $\begin{array}{c}0.212 \\
(0.116)\end{array}$ & $\begin{array}{c}0.222 \\
(0.119)\end{array}$ & $\begin{array}{c}0.233^{*} \\
(0.115)\end{array}$ \\
\hline 11 th Grade & $\begin{array}{c}0.101 \\
(0.120)\end{array}$ & $\begin{array}{c}0.102 \\
(0.119)\end{array}$ & $\begin{array}{c}-0.080 \\
(0.101)\end{array}$ & $\begin{array}{c}-0.082 \\
(0.101)\end{array}$ & $\begin{array}{c}0.196^{* k} \\
(0.076)\end{array}$ & $\begin{array}{l}0.200^{* *} \\
(0.077)\end{array}$ & $\begin{array}{c}0.070 \\
(0.083)\end{array}$ & $\begin{array}{c}0.078 \\
(0.079)\end{array}$ \\
\hline Two parent household & $\begin{array}{c}0.014 \\
(0.078)\end{array}$ & $\begin{array}{c}0.016 \\
(0.079)\end{array}$ & $\begin{array}{c}0.071 \\
(0.075)\end{array}$ & $\begin{array}{c}0.068 \\
(0.076)\end{array}$ & $\begin{array}{r}-0.076 \\
(0.084)\end{array}$ & $\begin{array}{r}-0.065 \\
(0.084)\end{array}$ & $\begin{array}{c}0.130 \\
(0.118)\end{array}$ & $\begin{array}{c}0.153 \\
(0.115)\end{array}$ \\
\hline Disabled & $\begin{array}{c}-0.249 \\
(0.226)\end{array}$ & $\begin{array}{c}-0.253 \\
(0.225)\end{array}$ & $\begin{array}{c}0.329 \\
(0.2\lfloor 7)\end{array}$ & $\begin{array}{c}0.337 \\
(0.215)\end{array}$ & $\begin{array}{c}-0.127 \\
(0.164)\end{array}$ & $\begin{array}{c}-0.150 \\
(0.163)\end{array}$ & $\begin{array}{c}0.408 \\
(0.323)\end{array}$ & $\begin{array}{c}0.356 \\
(0.323)\end{array}$ \\
\hline Citizen & $\begin{array}{c}0.236 \\
(0.307)\end{array}$ & $\begin{array}{c}0.235 \\
(0.307)\end{array}$ & $\begin{array}{c}-0.163 \\
(0.254)\end{array}$ & $\begin{array}{c}-0.162 \\
(0.254)\end{array}$ & $\begin{array}{c}0.135 \\
(0.196)\end{array}$ & $\begin{array}{c}0.134 \\
(0.197)\end{array}$ & $\begin{array}{c}-0.034 \\
(0.329)\end{array}$ & $\begin{array}{c}-0.036 \\
(0.33 I)\end{array}$ \\
\hline School Characteristics & & & & & & & & \\
\hline Catholic & $\begin{array}{c}0.015 \\
(0.100)\end{array}$ & $\begin{array}{c}0.017 \\
(0.101)\end{array}$ & $\begin{array}{c}0.031 \\
(0.094)\end{array}$ & $\begin{array}{c}0.027 \\
(0.094)\end{array}$ & $\begin{array}{c}-0.011 \\
(0.087)\end{array}$ & $\begin{array}{c}0.002 \\
(0.087)\end{array}$ & $\begin{array}{c}-0.347^{* *} \\
(0.122)\end{array}$ & $\begin{array}{c}-0.320^{\text {mat }} \\
(0.117)\end{array}$ \\
\hline Charter & $\begin{array}{c}-0.018 \\
(0.211)\end{array}$ & $\begin{array}{c}-0.018 \\
(0.211)\end{array}$ & $\begin{array}{r}-0.055 \\
(0.259)\end{array}$ & $\begin{array}{c}-0.054 \\
(0.258)\end{array}$ & $\begin{array}{c}0.038 \\
(0.156)\end{array}$ & $\begin{array}{c}0.032 \\
(0.158)\end{array}$ & $\begin{array}{c}-0.229 \\
(0.198)\end{array}$ & $\begin{array}{c}-0.243 \\
(0.201)\end{array}$ \\
\hline
\end{tabular}


Table 4. Continued

\begin{tabular}{|c|c|c|c|c|c|c|c|c|}
\hline Intercept & $\begin{array}{c}-2.351 * * \\
(0.331)\end{array}$ & $\begin{array}{c}-2.366^{* * *} \\
(0.331)\end{array}$ & $\begin{array}{l}1.737^{*} \\
(0.269)\end{array}$ & $\begin{array}{l}1.767^{* * *} \\
(0.261)\end{array}$ & $\begin{array}{r}-0.648^{*} \\
(0.273)\end{array}$ & $\begin{array}{c}-0.744 \\
(0.279)\end{array}$ & $\begin{array}{c}-2.536^{*} \\
(0.357)\end{array}$ & $\begin{array}{c}-2.802 \\
(0.360)\end{array}$ \\
\hline Pseudo $\mathrm{R}^{2}$ & 0.026 & 0.026 & 0.021 & 0.021 & 0.014 & 0.015 & 0.020 & 0.025 \\
\hline $\mathrm{N}$ & 4,427 & 4,427 & 4,427 & 4,427 & 4,427 & 4,427 & 4,427 & 4,427 \\
\hline
\end{tabular}

$p<.05, * 0.01, * 0.001$.

Note: Robust standard errors in parentheses. Analyses are adjusted for clustering of students within schools. Missing covariates (with the exception of gender and race) are mean substituted; dummy variables flagging missing covariates are included in the analyses but not shown. 
by adult authorities, intrude on this ideal identity, causing dissonance between the images of the heroic past and the weight of the present. In the end, the youth questions whether the acts of mobilization associated with the civil rights movement matter for the everyday realities of prejudice and racism that he experiences, and he wonders whether he can live up to the heroic deeds of the past.

Also in partial support of Hypothesis 5, Latino/a youth were more likely than white youth to claim they would mobilize law in response to a hypothetical rights violation, both in the baseline model $(0.325 ; p<0.01)$ and when taking into account actual (past) experiences with perceived rights violations $(0.302 ; p<0.01)$. In partial support of Hypothesis 6, Asian American students were somewhat less likely than white students to claim they would engage in quasi-legal action both in the baseline model $(-0.258$; $p<0.05$ ) and when taking into account past experiences with rights violations $(-0.264 ; p<0.05)$. Again, the model minority stereotype may play into these patterns and resonates with some of the difficulties alluded to earlier in the article in an excerpt from an interview with an Asian American respondent who repeatedly experienced peer harassment.

Other significant, non-hypothesized results also emerged in the findings relevant to ethnoracial identity and responses to hypothetical rights violations. Latino/a youth were more likely than white students to claim they would do nothing both in the baseline model $(0.247 ; p<0.05)$ and when taking into account past experiences with rights violations $(0.245 ; p<0.05)$. Latino/a youth were also less likely than white students to claim they would take extralegal action in the baseline model $(-0.255 ; p<0.05)$ and when taking into account past experiences with perceived rights violations $(-0.252 ; p<0.05)$. Again, these findings may result in the uneven ways that the interplay between the myth of law and rights and the realities of everyday life constitute the legal consciousness of minority youth. Finally, those students who identified themselves as "other" were more likely than white students to claim they would take formal legal action both in the baseline (0.593; $p<0.001)$ and when taking into account past experiences with rights violations $(0.541 ; p<0.001)$. Although our measure of ethnoracial identity in our survey did not, unfortunately, enable us to discern what specific ethnoracial categories "other" respondents identify with, previous survey research by T. Lee (2009) suggests that survey respondents who self-identify as "white" or "Asian American" are least likely to check "other" in categorical schemes. Thus, it may be that "other" students in our survey were more likely to be mixed African American and/or Latino/a, and therefore were similar in profile to our African American and Latino/a respondents. 


\section{Multivariate Analyses of Responses to Actual Rights Violations}

Table 5 provides little statistical support for Hypotheses 7 or 8 , save for the finding that Latino/a youth are less likely than white youth $(-0.767 ; p<0.05)$ to report mobilizing law in response to an actual rights violation. The results for African American youth with respect to mobilizing formal law were negative $(-0.480)$ but did not reach minimal statistical significance at the 0.05 level. ${ }^{11}$ Our qualitative interview data, however, suggest nuances that our survey data cannot capture and that, in many ways, are consistent with the theoretical logics undergirding Hypothesis 7.12

Consider this representative interview excerpt from a selfidentified "Mexican" junior female that we interviewed at a California school. She talked about student responses to a teacher's unwanted actions, which helps unpack our survey result that Latino/a youth are less likely than white youth to take formal legal action when they experience a rights violation:

There's this teacher-I think he abuses rights with a lot of the girls, making them feel extremely uncomfortable because he might very well be attracted to younger girls. And most of these girls don't speak up because, number one, they don't want to cause problems. ... Like, myself, I don't know how comfortable I would be speaking out against him, just because I'm afraid of the repercussions....

In this and other interviews, Latino/a youth used rights to refer to normative boundaries across which adults (and sometimes peers) should not transgress but which do not in and of themselves ensure protection from such transgressions. A key feature of this respondent's comments was "repercussions," which we learned from this respondent and her peers included anxieties about interpersonal retribution from teachers (for example, by grading a student "extra hard") and/or fear about one's complaint to "official" authorities somehow leading to an investigation of one's family or friends for possible violations of imigre (immigration) law. Indeed, these comments were quite representative of Latino/a and African American youths' sense of the constant surveillance and discipline they face in schools. As noted earlier, youth are quite aware of the differential power between them and their teachers. For Latino/a

11 Although a number of other individual-level results attained statistical significance, due to space limitations we only note one: disabled were more likely than nondisabled youth to take both quasi-legal $(0.421 ; p<0.05)$ and formal legal actions $(0.932 ; p<0.001)$ in response to perceived past rights violations. This result comports with previous research suggesting that students (and parents) embedded in services designed to serve the disabled become quite aware of the legal options open to them in dealing with rights violations (Barnett \& Scotch 2001).

12 Space limitations preclude us from discussing the full range of nonhypothesized, statistically significant patterns in our analyses not involving race and ethnicity. 
Table 5. Models Estimating the Likelihood of Taking Action Against a Perceived (Past) Rights Violation

\begin{tabular}{|c|c|c|c|c|}
\hline & Do Nothing & Extra Legal & Quasi Legal & Formal Legal \\
\hline Variables & $\begin{array}{c}\text { Baseline } \\
\text { Model }\end{array}$ & $\begin{array}{c}\text { Baseline } \\
\text { Model }\end{array}$ & $\begin{array}{c}\text { Baseline } \\
\text { Model }\end{array}$ & $\begin{array}{c}\text { Baseline } \\
\text { Model }\end{array}$ \\
\hline \multicolumn{5}{|l|}{ Individual Characteristics } \\
\hline Male & $\begin{array}{c}0.463^{2} \\
(0.089)\end{array}$ & $\begin{array}{c}-0.376 \\
(0.078)\end{array}$ & $\begin{array}{c}-0.151 \\
(0.084)\end{array}$ & $\begin{array}{c}0.806 \\
(0.260)\end{array}$ \\
\hline African American & $\begin{array}{c}-0.131 \\
(0.133)\end{array}$ & $\begin{array}{c}0.062 \\
(0.144)\end{array}$ & $\begin{array}{c}0.116 \\
(0.168)\end{array}$ & $\begin{array}{c}-0.480 \\
(0.357)\end{array}$ \\
\hline Latino/a & $\begin{array}{c}0.182 \\
(0.162)\end{array}$ & $\begin{array}{c}-0.171 \\
(0.168)\end{array}$ & $\begin{array}{l}0.06 \\
(0.158)\end{array}$ & $\begin{array}{r}-0.767^{*} \\
(0.346)\end{array}$ \\
\hline Asian & $\begin{array}{c}-0.105 \\
(0.190)\end{array}$ & $\begin{array}{c}0.157 \\
(0.141)\end{array}$ & $\begin{array}{r}-0.030 \\
(0.241)\end{array}$ & $\begin{array}{c}0.032 \\
(0.548)\end{array}$ \\
\hline Other & $\begin{array}{c}0.075 \\
(0.177)\end{array}$ & $\begin{array}{r}-0.143 \\
(0.130)\end{array}$ & $\begin{array}{c}-0.084 \\
(0.175)\end{array}$ & $\begin{array}{c}0.013 \\
(0.451)\end{array}$ \\
\hline $\begin{array}{l}\text { Parental education, } \\
\text { some college }\end{array}$ & $\begin{array}{r}-0.212 \\
(0.172)\end{array}$ & $\begin{array}{c}0.226 \\
(0.176)\end{array}$ & $\begin{array}{c}0.203 \\
(0.218)\end{array}$ & $\begin{array}{c}0.071 \\
(0.415)\end{array}$ \\
\hline $\begin{array}{l}\text { Parental education, } \\
\text { bachelor's degree }\end{array}$ & $\begin{array}{c}-0.044 \\
(0.135)\end{array}$ & $\begin{array}{r}-0.024 \\
(0.135)\end{array}$ & $\begin{array}{c}0.121 \\
(0.181)\end{array}$ & $\begin{array}{c}-0.013 \\
(0.300)\end{array}$ \\
\hline $\begin{array}{l}\text { Parental education, } \\
\text { graduate degree }\end{array}$ & $\begin{array}{r}-0.025 \\
(0.132)\end{array}$ & $\begin{array}{r}-0.012 \\
(0.138)\end{array}$ & $\begin{array}{c}0.125 \\
(0.198)\end{array}$ & $\begin{array}{r}-0.219 \\
(0.317)\end{array}$ \\
\hline 11 th Grade & $\begin{array}{c}0.011 \\
(0.114)\end{array}$ & $\begin{array}{c}0.004 \\
(0.099)\end{array}$ & $\begin{array}{c}0.093 \\
(0.108)\end{array}$ & $\begin{array}{r}-0.302 \\
(0.188)\end{array}$ \\
\hline Two parent household & $\begin{array}{r}-0.091 \\
(0.117)\end{array}$ & $\begin{array}{c}0.131 \\
(0.096)\end{array}$ & $\begin{array}{r}-0.049 \\
(0.107)\end{array}$ & $\begin{array}{c}0.340 \\
(0.208)\end{array}$ \\
\hline Disabled & $\begin{array}{c}0.210 \\
(0.221)\end{array}$ & $\begin{array}{c}-0.335 \\
(0.222)\end{array}$ & $\begin{array}{c}0.421^{*} \\
(0.212)\end{array}$ & $\begin{array}{l}0.932 \\
(0.227)\end{array}$ \\
\hline Citizen & $\begin{array}{r}-0.092 \\
(0.216)\end{array}$ & $\begin{array}{r}-0.016 \\
(0.214)\end{array}$ & $\begin{array}{c}0.348 \\
(0.307)\end{array}$ & $\begin{array}{c}0.203 \\
(0.543)\end{array}$ \\
\hline \multicolumn{5}{|l|}{ School Characteristics } \\
\hline Catholic & $\begin{array}{c}0.109 \\
(0.173)\end{array}$ & $\begin{array}{r}-0.125 \\
(0.143)\end{array}$ & $\begin{array}{c}-0.025 \\
(0.108)\end{array}$ & $\begin{array}{r}-0.206 \\
(0.299)\end{array}$ \\
\hline Charter & $\begin{array}{r}-0.332 \\
(0.244)\end{array}$ & $\begin{array}{c}0.084 \\
(0.210)\end{array}$ & $\begin{array}{c}0.302 \\
(0.198)\end{array}$ & $\begin{array}{c}-0.136 \\
(0.487)\end{array}$ \\
\hline South & $\begin{array}{c}0.267 \\
(0.164)\end{array}$ & $\begin{array}{r}-0.264 \\
(0.139)\end{array}$ & $\begin{array}{c}0.004 \\
(0.150)\end{array}$ & $\begin{array}{c}0.308 \\
(0.302)\end{array}$ \\
\hline West & $\begin{array}{r}0.423^{*} \\
(0.180)\end{array}$ & $\begin{array}{c}-0.430^{* * *} \\
(0.156)\end{array}$ & $\begin{array}{c}-0.284 \\
(0.157)\end{array}$ & $\begin{array}{r}-0.811^{*} \\
(0.353)\end{array}$ \\
\hline Intercept & $\begin{array}{l}-1.727 \\
(0.268)\end{array}$ & $\begin{array}{l}1.571^{*} \\
(0.278)\end{array}$ & $\begin{array}{c}-1.695^{-} \\
(0.359)\end{array}$ & $\begin{array}{c}-3.853^{\circ} \\
(0.624)\end{array}$ \\
\hline $\begin{array}{l}\text { Pseudo } \mathrm{R}^{2} \\
\mathrm{~N}\end{array}$ & $\begin{array}{l}0.017 \\
2,456\end{array}$ & $\begin{array}{l}0.015 \\
2,456\end{array}$ & $\begin{array}{l}0.010 \\
2,456\end{array}$ & $\begin{array}{l}0.072 \\
2,456\end{array}$ \\
\hline
\end{tabular}

${ }^{\star} p<.05, p<.01, p<.001$.

Note: Robust standard errors in parentheses. Analyses are adjusted for clustering of students within schools. Missing covariates (with the exception of gender and race) are mean substituted; dummy variables flagging missing covariates are included in the analyses but not shown.

youth we interviewed, especially in California, however, law was strongly woven into this sense of vulnerability that placed them one step away from having their lives disrupted, if not destroyed, by unwanted and unpredictable legal incursions.

This fear could also be discerned in the discourse of adults, especially administrators working with lower-income Latino/a student populations with high numbers of recently arrived 
immigrants from Mexico and Central America. Consider the comments from this self-identified "white" administrator:

Interviewer: I realize there may be differences across students, but tell me a bit how Latino youth handle problems that might arise with teachers involving, for example, a situation where they feel they've been discriminated against in some way.

Administrator: Look, kids from Mexico, El Salvador, Guatemala, they don't want any trouble. If some problem happens with a teacher or other students, we invite them to come to us, to figure it out, to file grievance if it's warranted.

Interviewer: Do they come in?

Administrator: Not really.

Interviewer: Why?

Administrator: I know for a fact that they're scared if they come that someone might start investigating their family or something.... They don't always understand how the system works.... We're not going to do that. We're here to educate kids, not deport 'em.

Interviewer: What about Anglo kids?

Administrator: Anglos, white kids, they'll make a helluva lot of noise -their parents will threaten a lawsuit ... [they] know the system and how to use it ... have the money to do that, whatever. They're not afraid of what might happen to them. They'll stir the pot.

This administrator obliquely suggested that Latino/a youth may not do anything ("don't want any trouble") when faced with trouble they define as discrimination by a teacher (which is consistent with Hypothesis 8). He also summarized his sense of the fear that we encountered among Latino/a youth regarding both formal law and quasi-legal action in schools (e.g., "they're scared" and "don't always understand how the system works"), and drew a normative boundary between the school's primary purpose (education) and the goals of legal officials outside the school regarding the policing of undocumented persons. The administrator also signaled his perception about the relationship between white students, material resources, and the likelihood of formal legal mobilization, which is quite different from the sense we encountered among white youth that, from their perspectives, youth would generally not mobilize formal law or go to internal authorities with grievances against teachers. The administrator's statements, however, do resonate with long-standing research findings that the "haves come out ahead" in legal mobilization because of material resources and knowledge about the law (Galanter 1974), as well as Lareau's (2003) work regarding the activist role that middle-class parents (both white and nonwhite) play in steering their children through schools. Moreover, the administrator's statements, together with our data from youth, speak to the complexities of perceptions 
across youths and adults with respect to legal consciousness and mobilization in schools.

In addition to fear among Latinos/as, interviews with African American youth revealed the unfairness and resignation with which African American youth regarded how their schools handle rights violations and discipline. This qualitative pattern resonates with the theoretical logic undergirding Hypothesis 7 regarding the general distrust of law among African Americans, especially police, and the everyday realities faced by African American youth. In the following exchange with an interviewer, an African American male junior from a North Carolina school commented on a recent "race riot" on his campus:

Student: We had a race riot not too long ago.

Interviewer: I remember hearing about that.

Student: Yeah.

Interviewer: What happened with it?

Student: You know, so, a friend of mine named Joseph, ${ }^{13}$ he was walking or something, and Harold, you know, being a white guy, you know, said something about him being a nigger. And so that's how it all started.

Interviewer: Wow.

Student: So that escalated from there.

Interviewer: OK. And so what did the school do about that?

Student: They had police here for a while, but, you know, I thought-I almost-I looked at it like they were protecting Harold, you know? They had him in an ISS [in-school suspension] room. Nobody could come in. He was, you know, surrounded by police. You know, if I would have said I was going to do some stuff like that, I would have been suspended for 10 days and he got suspended for three. So, you know, I think it was a little messed up, but it's not my decision on what happens here.

In the excerpt above, law is embodied by the police, who physically "surround" and "protect" a white perpetrator. The respondent further imagined the discipline and discrimination he would have suffered as an African American student if he, rather than the white student, was a key perpetrator in the "race riot" ("I would have been suspended for 10 days, and he got suspended for three"). The respondent resigned himself to the idea that there was little possibility he could shape in-school decisionmaking or outcomes in such matters.

The everyday realities for taking quasi-legal action in schools also appear in other student interviews. In one such interview, the interviewer asked an African American male senior at a New York

${ }^{13}$ All student names are pseudonyms. 
school what options he considered for dealing with disagreements with teachers:

Interviewer: When you have disagreements with teachers, do you
ever consider any other options for addressing them? Like talking
to an administrator or using a formal grievance process? Even
contacting a lawyer? Have you ever thought about it?
Student: Actually I haven't. Because what you get from it is
nothing is going to happen. ... The school is not really strict on
being yourself, like stand up for school rights. It's not like that.

Not only does it appear, then, that African Americans become resigned to injustices given their past experiences, but African American males, not surprisingly, seem the most resigned. Even as the previous two excerpts highlight a sense of resignation, they also suggest youths' sense of connection to the larger injustices in play and that law should perhaps protect their rights but does not.

\section{Conclusions}

At the outset of this article, we asked how rights matter for youth in American high schools. Slightly more than half the students in our survey sample reported experiencing rights violations, but students self-identifying as African American, Latino/a, and "other" reported rights violations at significantly higher rates than students self-identifying as Asian American or white. Regardless of ethnoracial identification, the vast majority of youth reported in surveys and in-depth interviews that they would handle a rights violation via extralegal means. In general, youths recognize they have "rights" in the abstract (whether based in law or not), but they understand the limitations of rights given the social realities of everyday school life. When asked in surveys how they would respond to rights violations in hypothetical scenarios, however, African American, Latino/a, and students identifying as "other" were more likely than white and Asian American youth to claim they would take formal legal action. In response to actual rights violations, despite experiencing higher rates of rights violations than white students, African American, Asian American, and students self-identifying as "other" were no more likely than white youth, and Latino/a youth were less likely than white youth, to report taking formal legal action. Although all youth have become more subject to criminal justice technologies and control in American schools during the past 30 years (Simon 2007:20731 ), we argue that the paradox of rights and race among youth in schools is integrally linked to disjunctions in schools between the myth of rights as a means of social justice and the disproportionate punishment and stigmatization experienced by African American and Latino/a youth (Kupchik 2009; Welch \& Payne 2010). For Asian 
American youth, the paradox may be more linked to the social tensions they experience as being socially constructed as a model minority. In multiple ways, then, the paradox of rights and race in American high schools facilitates ethnoracial inequality between white and nonwhite youth.

That more than half our survey sample of youth could recall a rights violation within the "legal grid" (Ewick \& Silbey 1998:237) of discrimination, sexual harassment, freedom of expression, and discipline also speaks to the moral force of rights to organize youth perceptions of and reactions to particular kinds of trouble in their everyday lives. Our qualitative data especially illustrate how youth draw on notions of rights to draw normative boundaries between justice and injustice, construct the moral character of their schools, and locate themselves in the institutional fabric of their campuses. At the same time, the great preponderance of extralegal action among all youth underscores how they, like adults, most often draw on normative orders apart from law to respond to trouble even when they define it in conceptual terms recognizable in some way as law. Given the contingent and experimental nature of adolescence (Dornbusch 1989), as well as the exclusion of youth from voice in the institutional authority that governs much of their lives (Morrill \& Musheno, forthcoming), it is especially important to understand the connections between normative orders during this developmental period because it may reveal how youth form the cognitive and behavioral habits (Gross 2009) that inform legal consciousness in adulthood.

Especially important along these lines is exploration of the agency and inventiveness youth hint at when discussing extralegal action, which we have only touched upon in this article, and the interactional dynamics through which they constitute their selfidentities in contexts of changing legal and school policies. Indeed, the potential tensions between these multiple orders and lines of action could even function as a form of education for youth about how institutionalized authority and unfair discipline are socially constructed and can be challenged (e.g., Ewick \& Silbey 1998:2389; Morrill, Zald, et al. 2003). The nationwide immigration protests in 2006, for example, in which thousands of Latino/a high school students participated (Archibold 2006), demonstrate that under certain conditions, students can act collectively in the pursuit of social justice. To be sure, there is always a mixture of social and material conditions that make collective action of any sort possible (Edelman, McAdam, et al. n.d.; McAdam et al. 1996). Based on our in-depth interviews, we speculate that the nascent sense of rights and their linkage to broader social injustices expressed among nonwhite youth could provide the ideational foundations for a collective "oppositional consciousness" to facilitate political mobilization (Mansbridge 2001). 
By concentrating on ethnoracial identification among youth, we have focused on only one part of the puzzle of law and social inequality in American schools, but we recognize that future work must systematically examine the intersectionality of multiple kinds of identities and social positions (especially gender and social class) as they relate to legal mobilization and consciousness among youth (e.g., Crenshaw 1988). Related to this first direction for future research is the need for research on the intersection of material and symbolic resources in constraining or facilitating formal mobilization. Many of the youth we interviewed emphasized symbolic and emotional constraints, which is consistent with earlier research (e.g., Bumiller 1988), but we recognize that such constraints themselves may be contextualized by class or regional contexts (Michelson 2007) or institutional fields (Edelman \& Suchman 1997). Future research should also use more sensitive measures of ethnoracial self-identification to consider the relationships between youth who identify with multiple racial and ethnic categories, and legal mobilization. A more sensitive measure of race and ethnicity might better represent some of the contingencies and fluidities of such identifications (e.g., T. Lee 2009), and how these dynamics relate to legal consciousness and mobilization. Finally, our research focuses on youth identity and legal mobilization at one point in time. Future research should move beyond snapshots of adolescent identity and legal mobilization to consider how these dynamics unfold over time in developmental and/or life course processes (Engel \& Munger 2003).

Methodologically, our research strongly suggests that the use of hypothetical stimuli alone can inflate or distort findings, particularly if the question concerns taking various legal actions. As social psychologists have long ago reminded us, there are often important discrepancies between what people say they will do and what they will in fact do (Deutscher 1966; LaPiere 1934). Our research further suggests that hypothetical studies are useful but especially valuable when they can be compared in some fashion to either selfreported experiences (which do, of course, have their own informant accuracy problems) or observations of actual behavior. It is in comparative perspective that either consistencies can be triangulated or inconsistencies can be identified that shed light on the interpretive mechanisms surrounding the phenomena of interest.

Finally, our expanded model of legal mobilization carries broader implications beyond youth for the study of legal mobilization and consciousness because adults, as well as youth, often seek to resolve rights violations outside the formal legal system. Especially as more and more organizations provide internal grievance procedures (Edelman 1990; Edelman \& Suchman 1999; Edelman, Uggen, et al. 1999), it seems critical that the concept of legal mobilization be expanded to include private forums for dispute resolution. As studies of 
everyday forms of law remind us, individuals who manage conflict via the aid of friends, the clergy, medical or other experts, or other types of authorities may be mobilizing their rights in ways that are important for the social construction of law and inequality even if they do not file formal legal claims (Engel \& Munger 2003). Our study shows how ethnoracial identity is critically bound up in legal mobilization, a process that it is integrally linked to the production and reproduction of social inequality.

\section{References}

Abrego, Leisy (2008) "Legitimacy, Social Identity, and the Mobilization of Law: The Effects of Assembly Bill 540 on Undocumented Students in California," 33 Law $\xi^{\circ}$ Social Inquiry 709-34.

Albiston, Catherine R. (2005) "Bargaining in the Shadow of Social Institutions: Competing Discourses and Social Change in Workplace Mobilization of Civil Rights," 39 Law E Society Rev. 11-49.

Aldrige, Derrick P. (2002) "Teaching Martin Luther King and the Civil Rights Movement in High School History Courses: Rethinking Content and Pedagogy," in J. B. Armstrong et al., eds., Teaching the American Civil Rights Movement: Freedom's Bittersweet Song. New Brunswick, NJ: Rutgers Univ. Press.

Ancheta, Angelo (2006) Race, Rights, and the Asian American Experience, 2d ed. New Brunswick, NJ: Rutgers Univ. Press.

Anderson, Elijah (1999) Code of the Street: Decency, Violence, and the Moral Life of the Inner City. New York: Norton.

Archibold, Randal C. (2006) "Immigrants Take to U.S. Streets in Show of Strength," The New York Times, National Section, 6 May, p. 1.

Arum, Richard (2003) Judging School Discipline: The Crisis of Moral Authority. Cambridge, MA: Harvard Univ. Press.

Barnett, Sharon N., \& Richard Scotch (2001) Disability Protests: Contentious Politics, 1970 1999. Washington, DC: Gallaudet Univ. Press.

Baumgartner, M. P. (1988) The Moral Order of a Suburb. New York: Oxford Univ. Press.

Berk, Hillary (2007) "School Environments: A Comparison of Civil Rights Law in California, New York, and North Carolina." Unpublished manuscript, Center for the Study of Law and Society, School of Law, University of California, Berkeley.

Best, Arthur, \& Alan Andreasen (1977) "Consumer Response to Unsatisfactory Purchases: A Survey of Perceiving Defects, Voicing Complaints, and Obtaining Redress," 11 Law E Society Rev. 701-42.

Black, Donald (1973) "The Mobilization of Law," 2 J. of Legal Studies 125-49.

—_ (1976) The Behavior of Law. New York: Academic Press. - (1983) "Crime as Social Control," 48 American Sociological Rev. 34-45.

Bloemraad, Irene, \& Christine Trost (2006) "It's a Family Affair: Intergenerational Mobilization in the Spring 2006 Protests," 52 American Behavioral Scientist 507-32.

Bumiller, Kristin (1987) "Victims in the Shadow of the Law: A Critique of the Model of Legal Protection," 12 Signs 421-34.

_ (1988) The Civil Rights Society: The Social Construction of Victims. Baltimore: Johns Hopkins Univ. Press.

Caplovitz, David (1963) Consumers in Trouble: A Study of Debtors in Default. New York: Free Press.

Carter, Prudence L. (2005) Keepin' It Real: School Success Beyond Black and White. Oxford: Oxford Univ. Press. 
Cintrón, Ralph (2000) "Listening to What the Streets Say: Vengeance as Ideology?" 567 The Annals of the American Academy of Political and Social Science (Volume on School Violence) 42-53.

Coleman, James S. (1961) Adolescent Society: The Social Life of the Teenager and Its Impact on Education. New York: Free Press.

Cooney, Mark (1998) Warriors and Peacemakers: How Third Parties Shape Violence. New York: New York Univ. Press.

Cortina, Lilia M. (2001) "Assessing Sexual Harassment Among Latinas: Development of an Instrument," 7 Cultural Diversity \& Ethnic Minority Psychology 164-81.

Crenshaw, Kimberlé Williams (1988) "Race, Reform, and Retrenchment: Transformation and Legitimation in Antidiscrimination Law," 101 Harvard Law Rev. 1331-87.

Curran, Barbara (1977) 7he Legal Needs of the Public: The Final Report of the National Survey. Chicago: American Bar Foundation.

Delgado, Richard, \& Jean Stefancic, eds. (2000) Critical Race Theory: The Cutting Edge, 2d ed. Philadelphia: Temple Univ. Press.

Deutscher, Irwin (1966) "Words and Deeds: Social Science and Social Policy," 13 Social Problems 235-54.

Dornbusch, Sanford (1989) “The Sociology of Adolescence," 15 Annual Rev. of Sociology 233-59.

Dunn, Joe P. (2005) "Teaching the Civil Rights Era: A Student-Active Approach," 38 The History Teacher 455-68.

Earl, Jennifer, et al. (2003) "Protest Under Fire? Explaining the Policing of Protest," 68 American Sociological Rev. 581-606.

Edelman, Lauren B. (1990) "Legal Environments and Organizational Environments: The Expansion of Due Process in the American Workplace," 96 American Journal of Sociology $1401-40$.

Edelman, Lauren B., Howard S. Erlanger, et al. (1993) "Internal Dispute Resolution: The Transformation of Civil Rights in the Workplace," 27 Law E' Society Rer. 497-534.

Edelman, Lauren B., Christopher Uggen, et al. (1999) "The Endogeneity of Legal Regulation: Grievance Procedures as Rational Myth," 105 American J. of Sociology 406-54.

Edelman, Lauren B., \& Doug McAdam, et al. (n.d.) "Law, Social Movements and Organizations," 6 Annual Rev. of Law and Social Science, forthcoming

Edelman, Lauren B., \& Mark C. Suchman (1997) "The Legal Environments of Organizations," 23 Annual Rev. of Sociology 479-515.

__ (1999) "When the 'Haves' Hold Court: The Internalization of Disputing in Organizational Fields," 33 Law $\&$ Society Rev. 941-91.

Ellickson, Robert (1991) Order Without Law: How Neighbors Settle Disputes. Cambridge, MA: Harvard Univ. Press.

Emerson, Robert M. (2008) "Responding to Roommate Troubles: Reconsidering Informal Dyadic Control," 42 Law Ė Society Rev. 483-512.

Emerson, Robert M., et al. (1995) Writing Ethnographic Fieldnotes. Chicago: Univ. of Chicago Press.

Engel, David M., \& Frank W. Munger (2003) Rights of Inclusion: Law and Identity in the Life Stories of Americans with Disabilities. Chicago: Univ. of Chicago Press.

Erikson, Erik H. (1968) Identity, Youth, and Crisis. New York: W. W. Norton.

Ewick, Patricia, \& Susan S. Silbey (1998) The Common Place of Law: Stories From Everyday Life. Chicago: Univ. of Chicago Press. (2003) "Narrating Social Structure: Stories of Resistance to Legal Authority," 108 American J. of Sociology 1328-72.

Fagan, Jeffrey, \& Tom R. Tyler (2005) "Legal Socialization of Children and Adolescents," 18 Social Justice Research J. $217-42$.

Felstiner, William L. F. (1974) "Influences of Social Organization on Dispute Processing," 9 Law E Society Rev. 63-94. 
Felstiner, William L. F., et al. (1980-81) "The Emergence and Transformation of Disputes: Naming, Blaming, Claiming ....," 15 Law E Society Rev. 631-54.

Ferguson, Ann Arnett (2000) Bad Boys: Public Schools in the Making of Black Masculinity. Ann Arbor: Univ. of Michigan Press.

Fine, Michelle, et al. (2003) "Anything Can Happen With Police Around: Urban Youth Evaluate Strategies of Surveillance in Public Places," 59 J. of Social Issues $141-58$.

Flanagan, Constance, \& Lonnie Sherrod (1998) "Youth Political Development," $54 \mathrm{~J}$. of Social Issues 447-56.

Friedman, Lawrence (1985) Total Justice. New York: Russell Sage Foundation.

Fuller, Sally Riggs, et al. (2000) "Legal Readings: Employee Interpretation and Mobilization of Law," 25 The Academy of Management Rev. 200-16.

Galanter, Marc (1974) “"Why the 'Haves' Come Out Ahead: Speculations on the Limits of Legal Change," 9 Law E' Society Rev. 95-160.

- (1983) "Reading the Landscape of Disputes: What We Know and Don't Know (and Think We Know) About Our Allegedly Contentious and Litigious Society," 31 UCLA Law Rev. 4-71.

Garot, Robert (2007) "Inner-City Teens and Face-Work: Avoiding Violence and Maintaining Honor," in L. Monaghan \& J. E. Goodman, eds., A Cultural Interpersonal Communication: Essential Readings. Oxford: Blackwell.

(2009) "Reconsidering Retaliation: Structural Inhibitions, Emotive Dissonance, and the Acceptance of Ambivalence Among Inner-City Young Men," 10 Ethnography 63-90.

Gómez, Laura E. (2004) "A Tale of Two Genres: On the Real and Ideal Links Between Law and Society and Critical Race Theory," in A. Sarat, ed., The Blackwell Companion to Law and Society. London: Blackwell.

Gross, Neil (2009) "A Pragmatist Theory of Social Mechanisms," 74 American Sociological Rev. 358-79.

Hagan, John, Paul Hirschfield, et al. (2002) "First and Last Words: Apprehending the Social and Legal Facts of an Urban High School Shooting," 31 Sociological Methods E Research 218-54.

Hagan, John, Carla Shedd, et al. (2005) "Race, Ethnicity, and Youth Perceptions of Criminal Injustice," 70 American Sociological Rev. 381-407.

Hallinan, Maureen (2001) "Sociological Perspectives and Black-White Inequality in American Schooling," 74 Sociology of Education 50-70.

Haney López, Ian F. (2003) Racism on Trial: The Chicano Fight for Justice. Cambridge, MA: Belknap Harvard.

Heimer, Carol A. (1999) "Competing Institutions: Law, Medicine, and Family in Neonatal Care Units," 33 Law Ẽ Society Rev. 17-66.

Helwig, Charles C. (1995) "Adolescents' and Young Adults' Conceptions of Civil Liberties: Freedom of Speech and Religion," 66 Child Development 152-66.

Hess, Frederick M. (2008) Still at Risk: What Students Don't Know, Even Now. Washington, DC: Common Core.

Hirsh, C. Elizabeth, \& Sabino Kornrich (2008) "The Context of Discrimination: Workplace Conditions, Institutional Environments, and Sex and Race Discrimination Charges," 113 American J. of Sociology 1394-432.

Hoffman, Elizabeth A. (2003) "Legal Consciousness and Dispute Resolution: Different Disputing Behavior at Two Similar Taxi Cab Companies," 26 Law E Social Inquiry 693-716.

- (2005) "Dispute Resolution in a Worker Cooperative: Formal Procedures and Procedural Justice," 39 Law \& Society Rev. 51-82.

Kessler, Ronald C., et al. (1999) "The Prevalence, Distribution, and Mental Health Correlates of Perceived Discrimination in the United States," $40 \mathrm{~J}$. of Health and Social Behavior 208-30. 
King, Donald W., \& Kathleen A. McEvoy (1976) A National Survey of the Complaint Handling Procedures Used by Consumers. Rockville, MD: King Research.

Kirp, David L. (1982) Just Schools: The Idea of Racial Equality in America Education. Berkeley: Univ. of California Press.

Krisberg, Barry (2008) "The Politics of the War Against the Young," in M. L. Frampton et al., eds., After the War on Crime: Race, Democracy and a New Reconstruction. New York: New York Univ. Press.

Kritzer, Herbert M. (1980-81) "Studying Disputes: Learning from the CLRP Experience," 15 Law E Society Rev. 503-24.

Kupchik, Aaron (2009) "Things Are Tough All Over: Race, Ethnicity, and School Discipline," 11 Punishment E Society 291-317.

LaPiere, Richard T. (1934) "Attitudes vs. Actions," 13 Social Forces 230-7.

Lareau, Annette (2003) Unequal Childhoods: Class, Race, and Family Life. Berkeley: Univ, of California Press.

Lee, Jennifer, \& Frank D. Bean (2004) "America's Changing Color Lines: Immigration, Race/Ethnicity, and Multiracial Identification," 30 Annual Rev. of Sociology $221-42$.

Lee, Stacey J. (2009) Unraveling the Myth of the "Model Minority" Stereotypes: Listening to Asian American Youth, $2 \mathrm{~d}$ ed. New York: Teachers College Press.

Lee, Taeku (2009) "Between Theory and Social Science Practice: Toward a New Approach to the Survey Measurement of Race," in R. Abdelal et al., eds., Measuring Identity: A Guide for Social Scientists. Cambridge, UK: Cambridge Univ. Press.

Lee, Valerie E., et al. (1996) "The Culture of Sexual Harassment in Secondary Schools," 33 American Educational Research J. 383-417.

Lofland, John, et al. (2005) Analyzing Social Settings, 4th ed. Belmont, CA: Wadsworth.

Lundman, Richard J., \& Robert L. Kauffman (2003) "Driving While Black: Effects of Race, Ethnicity, and Gender on Citizen Self-Reports of Traffic Stops and Police Actions," 41 Criminology 195-220.

Macaulay, Stewart (1963) "Non-Contractual Relations in Business: A Preliminary Study," 28 American Sociological Rev. 55-67.

Mansbridge, Jane (2001) "The Making of Oppositional Consciousness," in J. Mansbridge \& A. Morris, eds., Oppositional Consciousness: The Subjective Roots of Social Protest. Chicago: Univ. of Chicago Press.

Marshall, Anna-Maria (2003) "Injustice Frames, Legality, and the Everyday Construction of Sexual Harassment," 28 Law E Social Inquiry 761-93.

- (2005) "Idle Rights: Employees' Rights Consciousness and the Construction of Sexual Harassment Policies," 39 Law E Society Rev. 83-124.

Mayhew, Leon, \& Albert J. Reiss (1969) "The Social Organization of Legal Contacts," 34 American Sociological Rev. 309-18.

McAdam, Doug (1988) Freedom Summer. New York: Oxford Univ. Press.

McAdam, Doug, et al., eds. (1996) Comparative Perspectives on Social Movements: Political Opportunities, Mobilizing Structures, and Cultural Framings. Cambridge, UK: Cambridge Univ. Press.

McCann, Michael W. (1994) Rights at Work: Pay Equity Reform and the Politics of Legal Mobilization. Chicago: Univ. of Chicago Press.

McFarland, Daniel A. (2001) "Student Resistance: How the Formal and Informal Organization of Classrooms Facilitate Everyday Forms of Student Defiance," 107 American J. of Sociology 612-78.

-_ (2004) "Resistance as Social Drama: A Study of Change-Oriented Behaviors," 109 American J. of Sociology 1249-318.

McNeil, Kenneth, et al. (1979) "Market Discrimination Against the Poor and the Impact of Consumer Disclosure Laws: The Used Car Industry," 13 Law E Sociely Rev. $695-720$. 
Menjivar, Cecelia, \& Cynthia Bejarano (2003) "Latino Immigrants' Perceptions of Crime and Police Authorities in the United States: A Case Study from the Phoenix Metropolitan Area," 26 Ethnic and Racial Studies 120-48.

Merry, Sally Engel (1990) Getting Justice and Getting Even: Legal Consciousness Among Working-Class Americans. Chicago: Univ. of Chicago Press.

Michelson, Ethan (2007) "Climbing the Dispute Pagoda: Grievances and Appeals to the Official Justice System in Rural China," 72 American Sociological Rev. 459-85.

Miller, Richard E., \& Austin Sarat (1980-81) "Grievances, Claims, and Disputes: Assessing the Adversarial Culture," 15 Law E Society Rez. 525-56.

Mnookin, Robert H., \& Lewis Kornhauser (1979) "Bargaining in the Shadow of Law: The Case of Divorce," 88 Vale Law J. 950-97.

Morrill, Calvin (1995) The Executive Way: Conflict Management in Corporations. Chicago: Univ. of Chicago Press.

Morrill, Calvin, \& Michael Musheno (n.d.) Youth Confict: Culture and Control in a Multiethnic High School. Manuscript in progress, Center for the Study of Law and Society, School of Law, University of California, Berkeley.

Morrill, Calvin, Christine Yalda, et al. (2000) "Telling Tales in School: Youth Culture and Conflict Narratives," 34 Law E Society Rev. 521-65.

Morrill, Calvin, Mayer N. Zald, et al. (2003) "Covert Political Conflict: Challenges from Below," 29 Annual Reu. of Sociology 391-415.

Motomura, Hiroshi (2006) Americans in Waiting: The Lost Story of Immigration and Citizenship in the United States. Oxford: Oxford Univ. Press.

Nader, Laura, \& Harry F. Todd, Jr., eds. (1978) The Disputing Process - Law in Ten Societies. New York: Columbia Univ. Press.

Nielsen, Laura Beth (2004) License to Harass: Law, Hierarchy, and Offensive Public Speech. Princeton, NJ: Princeton Univ. Press.

Nielsen, Laura Beth, \& Robert L. Nelson (2005) "Rights Realized? An Empirical Analysis of Employment Discrimination Litigation as a Claiming System," 2005 Wisconsin Law Rev. 663-711.

Oakes, Jeannie (1985) Keeping Track: How Schools Structure Inequality. New Haven, CT: Yale Univ. Press.

Obasogie, Osagie K. (2006) "Race in Law and Society: A Critique," in I. Haney-López, ed., Race, Law and Society. Burlington, VT: Ashgate.

Oberweis, Trish, \& Michael Musheno (1999) "Policing Identities: Cop Decision Making and the Constitution of Citizens," 24 Law $\mathfrak{E}^{2}$ Social Inquiry 897-923.

O'Dougherty, Maureen (2006) "Public Relations, Private Security: Managing Youth and Race at the Mall of America," 24 Enviromment and Planning D: Society Space 131-54.

Oliver, Melvin, \& Thomas Shapiro (2006) Black Wealth/White Wealth: A New Perspective on Racial Inequality, 2d ed. New York: Routledge.

Pager, Devah (2007) Marked: Race, Crime, and Finding Work in an Era of Mass Incarceration. Chicago: Univ. of Chicago Press.

Perry, Pamela (2002) Shades of White: White Kids and Racial Identities in High School. Durham, NC: Duke Univ. Press.

Polletta, Francesca (2006) It Was Like a Fever: Storytelling in Protest and Politics. Chicago: Univ. of Chicago Press.

Portes, Alejandro, \& Rubén G. Rumbaut (2001) Legacies: The Story of the Immigrant Second Generation. Berkeley: Univ. of California Press.

Rosenbloom, Susan Rakosi, \& Niobe Way (2004) "Experiences of Discrimination Among African American, Asian American, and Latino Adolescents in an Urban High School," 35 Youth and Society 420-51.

Rosigno, Vincent J., \& James W. Ainsworth-Darnell (1999) "Race, Cultural Capital, and Educational Resources: Persistent Inequalities and Achievement Returns," 72 Sociology of Education 158-78. 
Sampson, Robert J., \& Lydia Bean (2006) "Cultural Mechanisms and Killing Fields: A Revised Theory of Community-Level Racial Inequality," in R. D. Peterson et al., eds., The Many Colors of Crime: Inequalities of Race, Ethnicity, and Crime in America. New York: New York Univ. Press.

Sánchez-Jankowski, Martín (2008) Cracks in the Pavement: Social Change and Resilience in Poor Neighborhoods. Berkeley: Univ. of California Press.

Scheingold, Stuart A. (1974) The Politics of Rights: Lauyers, Public Policy, and Political Change. New Haven, CT: Yale Univ. Press.

Simon, Jonathan (2007) Governing Through Crime: How the War on Crime Transformed Democracy and Created a Culture of Fear. New York: Oxford Univ. Press.

Skelton, Tracey, \& Gill Valentine, eds. (1998) Cool Places: Geographies of Youth Cultures. London: Routledge.

Skrentny, John (2002) The Minority Rights Revolution. Cambridge, MA: Harvard Univ. Press.

Stockdill, Brett C. (2001) "Forging a Multidimensional Oppositional Consciousness: Lessons from Community-Based AIDS Activism,” in J. Mansbridge \& A. Morris, eds., Oppositional Consciousness: The Subjective Roots of Social Protest. Chicago: Univ. of Chicago Press.

Telles, Edward E., \& Vilma Ortiz (2008) Generations of Exclusion: Mexican Americans, Assimilation and Race. New York: Russell Sage Foundation.

Tyson, Karolyn, et al. (2005) "It's Not 'A Black Thing': Understanding the Burden of Acting White and Other Dilemmas of High Achievement," 70 American Sociological Rev. 582-605.

View, Jenice (2004) "Introduction," in J. View et al., eds., Putting Movement Back into Civil Rights Teaching. Washington DC: Teaching for Change.

Walters, Pamela Barnhouse, \& Carl M. Briggs (1993) "The Family Economy, Child Labor, and Schooling: Evidence from the Early Twentieth Century South," 58 American Sociological Rev. 163-81.

Warland, Rex H., et al. (1975) "Dissatisfied Consumers: Who Gets Upset and Who Takes Action," $9 \mathrm{~J}$. of Consumer Affairs 148-63.

Waters, Mary C., \& Karl Eschbach (1995) "Immigration and Racial and Ethnic Inequality in the United States," 21 Annual Rev. of Sociology 419-46.

Weis, Lois, \& Michelle Fine (2000) Construction Sites: Excavating Race, Class, and Gender Among Urban Youth. New York: Teachers College Press.

Welch, Kelly, \& Allison Ann Payne (2010) "Racial Threat and Punitive School Discipline," 57 Social Problems 25-48.

White, Rob, \& Johanna Wyn (2008) Youth $\xi^{2}$ Society: Exploring the Social Dynamics of Youth Experience. South Melbourne, Australia: Oxford Univ. Press.

Williams, Juan, \& Julian Bond (1988) Eyes on the Prize: America's Civil Rights Years, 19541965. New York: Penguin.

Williams, Barbara (2001) Lessons in Courage: Martin Luther King, Rosa Parks, and Ruby Bridges. Ell Alma Raza Curriculum and Teachers Training Program, Denver Public Schools.

Williams, Patricia (2000) "Alchemical Notes: Reconstructing Ideals from Deconstructed Rights," in R. Delgado \& J. Stefancic, eds., Critical Race Theory: The Cutting Edge, 2d ed. Philadelphia: Temple Univ. Press.

Young, Iris Marion (2000) "Structure, Difference, and Hispanic/Latino Claims of Justice," in J. J. E. Gracia \& P. De Grief, eds., Hispanics/Latinos in the United States. New York: Routledge.

Zatz, Marjorie S., \& Nancy Rodriguez (2006) "Conceptualizing Race and Ethnicity in Studies of Crime and Criminal Justice," in R. D. Peterson et al., eds., The Many Colors of Crime; Inequalities of Race, Ethnicity, and Crime in America. New York: New York Univ. Press. 


\title{
Cases Cited
}

\author{
Brown v. Board of Education of Topeka, 347 U.S. 483 (1954). \\ Coss v. Lopez, 419 U.S. 565 (1975). \\ Tinker च. Des Moines Independent School District, 393 U.S. 503 (1969).
}

\section{Statute Cited}

Rights Act of 1964, Pub. L. 88-352, 78 Stat. 241 (1964).

Calvin Morrill is Professor of Law and Sociology and Director of the Center for the Study of Law and Society at the University of Califormia, Berkeley. He has written extensively on social conflict and change in organizational, educational, and urban contexts. Among his publications are "Conflict Resolution in Organizations" (with Danielle Rudes, forthcoming in Annual Review of Law and Social Science); Together Alone: Personal Relationships in Public Places (co-edited with David Snow and Cindy White, University of Califormia Press, 2005); and The Executive Way: Conflict Management in Corporations (University of Chicago Press, 1996).

Lauren B. Edelman is Associate Dean for Jurisprudence and Social Policy, Agnes Roddy Robb Professor of Law, and Professor of Sociology at the University of California, Berkeley. Her research focuses on how organizations transform the meaning of law. Her recent publications include "On Law, Social Movements, and Organizations" (with Gwendolyn Leachman and Doug McAdam, forthcoming in Annual Review of Law and Social Science); "The Endogeneity of Law" in O'Brien (ed.), Private Equity, Corporate Governance, and the Dynamics of Capital Market Regulation (World Scientific, 2007); and The Legal Lives of Private Organizations (co-edited with Mark C. Suchman, Ashgate, 2007).

Karolyn Tyson is Associate Professor of Sociology at the University of North Carolina at Chapel Hill. Her research centers on understanding the complex interactions between schooling processes and student outcomes, particularly among black students. She is the author of Integration Interrupted: Tracking, Black Students, and Acting White after Brown (Oxford University Press, forthcoming).

Richard Arum is Professor of Sociology and Education, New York University. His research focuses on schooling, law, stratification, and criminology. He is author of Judging School Discipline: The Crisis of Moral Authority (Harvard University Press, 2003) and with Josipa Roksa, Academically Adrift: Limited Learning on College Campuses (University of Chicago Press, forthcoming). He also co-edited with Yossi Shavit and Adam Gamoran Stratification in Higher Education: A Comparative Study (Stanford University Press, 2007). 
